\title{
Pathology of midgut gland-cells of Penaeus monodon postlarvae after Leucaena leucocephala feeding
}

\author{
Günter Vogt \\ Department of Zoology 1 (Morphology/Ecology), University of Heidelberg, Im Neuenheimer Feld 230, D-6900 Heidelberg, \\ Federal Republic of Germany
}

\begin{abstract}
Leucaena leucocephala, one of the promising feed sources in aquaculture of tropical regions, induces drastic pathological alterations in the midgut gland (= hepatopancreas) cells of Penaeus monodon postlarvae. After $28 \mathrm{~d}$ feeding on a formulated diet containing Leucaena with natural mimosine content, the most severely affected cell type is the R-cell, followed by F-cells. B-cells are only rarely pathologically changed. Artificial reduction of mimosine content prior to diet formulation results in less severe signs of pathology. The course of cell injury suggests that the nucleus is one of the primary targets of Leucaena toxicity to midgut gland-cells. Pathology starts, in all cell types, with alterations in the fibrillar component of the nucleolus accompanied by fading of the nucleoplasm and cytoplasm. Thereafter, the heterochromatin of the cell nucleus is step-by-step decondensed. Obviously, structural components of the nucleolus organizer region are changed, thus leading to a cessation of rRNA synthesis and eventually of ribosome production. The simultaneous decondensation of the nuclear heterochromatin may cause disturbances of cell function and finally lead to cell lysis. Prawns may die of septicemia when high numbers of midgut gland epithelium cells are destroyed. From the cytoplasmic organelles, only the mitochondria and F-cell dictyosomes display disorders in the early stages of pathology. These alterations are probably nucleus-independent. The darkening of the mitochondrial matrix may be caused by depletion of oxidative phosphorylation due to enzyme inhibition, whereas the vacuolization of the Golgi-cisternae in F-cells is interpreted as cytoskeleton injury.
\end{abstract}

\section{INTRODUCTION}

The leaves of the leguminous shrub Leucaena leucocephala (hereafter Leucaena) are of growing interest in the search for a biologically viable and economical ingredient for formulated diets in aquaculture, particularly in tropical regions. Leucaena has an excellent nutritional potential and good digestibility values (NAS 1977). This rather cheap feedstuff is available throughout the tropics and has been successfully introduced in the markets of many tropical countries. Leucaena is already widely used as feed for livestock and poultry (Jones 1979, Jones \& Hegarty 1984). However, the use of Leucaena is limited by the toxic, nonprotein amino acid mimosine which is present in the leaves, stems and seeds, or by its degradation product dihydroxypyridine (DHP). The nutritional potential of Leucaena can be optimally utilized if the mimosine content is heavily reduced prior to diet formulation. Methods for artificial mimosine degradation have been summarized by Tangendjaja et al. (1984). In ruminant livestock, mimosine related problems can be solved by the transfer of mimosine and DHP degrading bacteria into the rumen of the cattle (Jones \& Megarrity 1986).

In contrast to agriculture, aquaculture feeding experiences with Leucaena are rather scarce (for references see Vogt et al. 1986, Wee \& Wang 1987). Our own 28-d experiment with formulated diets containing $20 \%$ dried Leucaena leaf meal gave better growth results in Penaeus monodon postlarvae than a control diet which contained the same feedstuff, but soybean instead of Leucaena (Vogt et al. 1986). Despite good growth in the group fed with a Leucaena diet of natural mimosine content, pathological alterations were observed in individual midgut gland-cells starting at Day 20. In the following period, these alterations 
spread over the whole epithelium. Less severe signs occurred in prawns fed with a Leucaena diet of reduced mimosine value. In both treatments, the pathological alterations did not result in enhanced mortality rates at the end of the 4-wk experiment. Pascual \& Tabbu (1980), however, reported on increasing mortalities after 6 wk feeding with comparable Leucaena diets, and complete mortality after $8 \mathrm{wk}$.

In this paper, the Leucaena-induced disorders of midgut gland-cells observed in our previous experiment (Vogt et al. 1986) are described in detail. Possible mechanisms of cytotoxicity are discussed taking into account the reported course of cytopathological alterations in Penaeus monodon and the known biochemical properties of mimosine.

\section{MATERIALS AND METHODS}

Postlarvae of the giant tiger prawn, Penaeus monodon Fabricius 1798 (Crustacea: Decapoda: Penaeidae), were fed for $28 \mathrm{~d}$ with formulated diets containing either $20 \%$ unsoaked or $20 \%$ soaked Leucaena leaves (ingredients: $20 \%$ Leucaena soaked or unsoaked, $30 \%$ fish meal, $15 \%$ shrimp meal, $10 \%$ bread flour, $9.8 \%$ rice bran, $9 \%$ cod liver oil, $5 \%$ potato starch, $0.95 \%$ vitamin-mineral-mix, $0.05 \%$ vitamin C, $0.2 \%$ butyl hydroxy toluene). Soaking of leaves in freshwater for $24 \mathrm{~h}$ prior to diet formulation reduced the amount of mimosine in the leaves from 2.49 to $0.74 \%$. The final mimosine content of formulated feed amounted to $0.76 \%$ in the 'unsoaked' diet and $0.25 \%$ in the 'soaked' diet. All data is on a dry weight basis. An identically formulated feed with soybean instead of Leucaena leaves was used as control. For detailed experimental design, culture method, food processing scheme, analytical data of the feed and weight gain of the postlarvae, see Vogt et al. (1986).

The midgut glands of prawns were investigated by means of light and electron microscopy at the start of the experiment and after 4,11, 20 and $28 \mathrm{~d}$ feeding (Table 1). For electron microscopic preparation, each gland was cut into 4 small portions, and fixed in cold $2.5 \%$ glutaraldehyde in Sörensen's buffer containing $5 \%$ sucrose at pH 7.2 for 2 h. After rinsing in Sörensen's buffer, tissues were postfixed in $1 \%$ osmium tetroxide a further $2 \mathrm{~h}$. Samples were then dehydrated through a series of graded ethanol, transferred to propylene oxide for $20 \mathrm{~min}$ and embedded in araldite. Ultrathin sections were cut with glass knives on a Reichert-Jung OM 2 ultramicrotome and contrasted. with uranyl acetate $(7 \mathrm{~min})$ and lead citrate $(5 \mathrm{~min})$ prior to examination under a Zeiss EM 9-S2 electron microscope. Light microscopic evaluation was performed using semithin sections which were obtained from the araldite blocks and stained with methylene blue-azur II (Richardson solution). To investigate pathological alterations, both semithin and ultrathin sections were taken from several parts of each araldite block. Since the whole gland of a postlarva is only ca $5 \times 2.5 \times 2.5 \mathrm{~mm}$, each section displayed between 5 to 10 tubules in various regions. Thus, the midgut glandtubules of all prawns could easily be investigated from the embryonic to proximal zone.

\section{RESULTS}

\section{Histopathology}

$$
\text { Midgut gland }
$$

At a distinct sampling time, pathological alterations in the midgut glands are much more severe in Penaeus monodon fed on unsoaked Leucaena than in those fed with the soaked diet. No pathology occurred in the soybean fed control (Table 1). A considerable variability in the degree of damage is observed in midgut glands of prawns from the same treatment (Table 1).

Surprisingly, the first slight signs of Leucaenacaused disturbances are visible at the organ level and not at the cell level. The epithelium of the midgut gland-tubules, which in cross sections normally shows 4 to 6 bulges and indentations (Fig. 1) gradually loses its structural integrity. After $11 \mathrm{~d}$ of feeding on unsoaked diet, slight irregularities of the epithelial infoldings are visible (e.g. additional division of bulges). These disturbances of the epithelial architecture increase with continued Leucaena feeding (Figs. 2 and 3).

At Day 11, only a very few cells of the whole gland are slightly changed. From Day 20, more pronounced damage of tubules originates from pathological alterations of individual cells (Figs. 2 and 3). The grades of pathology vary greatly between the tubules of one and the same midgut gland (Fig. 2). As long as only a few cells are destroyed, neighbouring cells protrude in small basolateral extensions like a wedge under the base of a pathological cell (Fig. 4). The pathological cell is thus gradually extruded into the tubular lumen (Fig. 5) while the neighbouring cells simultaneously close the gap (Fig. 6). Cells are expelled after complete lysis and sometimes also in earlier phases of pathological alteration (Fig. 6). As soon as the number of destroyed cells is too high, as observed in a few tubules of a single postlarva after $28 \mathrm{~d}$ feeding on unsoaked Leucaena, the gaps can no longer be closed. The consequences are ulceration of the epithelium in those heavily affected tubules (Fig. 7) 
Table 1. Penaeus monodon. Severity of pathology in individual midgut glands of prawns fed on soybean and Leucaena diets. Two postlarvae (A and B) were investigated per treatment and time; results were evaluated by light microscopy. Giades of pathology were estimated from cross sections of midgut gland-tubules and are as follows: (N) no signs; (VS) very slight - only a few pathological cells in a section of the whole gland; (S) small, $<20 \%$ of tubule sections with pathological cells; (C) considerable, 20 to $50 \%$; (H) high, 50 to $80 \%$; (VH) very high, > $80 \%$. Successive stages of cytopathological alteration are indicated by I, II, III; only dominant stages are listed

\begin{tabular}{|c|c|c|c|c|c|c|}
\hline \multirow[t]{2}{*}{$\begin{array}{l}\text { Time } \\
\text { (d) }\end{array}$} & \multicolumn{2}{|c|}{ Soybean } & \multicolumn{2}{|c|}{$\begin{array}{c}\text { Diet } \\
\text { Soaked Leucaena }\end{array}$} & \multicolumn{2}{|c|}{ Unsoaked Leucaena } \\
\hline & A & $B$ & A & $\mathrm{B}$ & A & $\mathrm{P}$ \\
\hline \multirow[t]{2}{*}{0} & $\mathrm{~N}$ & $N$ & N & $N$ & $\mathrm{~N}$ & $N$ \\
\hline & - & - & - & - & - & - \\
\hline \multirow[t]{2}{*}{4} & $N$ & $N$ & N & N & $N$ & $\mathrm{~N}$ \\
\hline & - & - & - & - & - & - \\
\hline \multirow[t]{2}{*}{11} & $\mathrm{~N}$ & $N$ & VS & VS & VS & $\mathrm{S}$ \\
\hline & - & - & $I$ & $\mathrm{I}$ & I & I \\
\hline \multirow[t]{2}{*}{20} & $\mathrm{~N}$ & $\mathrm{~N}$ & S & $\mathrm{S}$ & $\mathrm{C}$ & $\mathrm{H}$ \\
\hline & - & - & I & I, II & I, II & II \\
\hline \multirow[t]{2}{*}{28} & $N$ & $\mathrm{~N}$ & $\mathrm{~S}$ & $\mathrm{C}$ & $\mathrm{H}$ & VH \\
\hline & - & - & I, II & II & II, III & III \\
\hline
\end{tabular}

\section{Other tissues}

Few cells of the anterior part of the digestive tract and midgut, and very few epithelial cells of the antennal gland extensions running along the midgut gland, exhibit nucleoplasm and cytoplasm fading. Nearby blood cells and connective tissue cells display no pathological signs.

\section{Cytopathology}

Tissues obtained from prawns fed for 4 to $28 \mathrm{~d}$ on soybean or $4 \mathrm{~d}$ on Leucaena diets serve as controls. Only slight cytological differences are noted between healthy R-cells of soybean and Leucaena fed prawns. These are more abundant rER and supranuclear autophagosomes, and fewer, smaller lipid inclusions in the Leucaena groups (Vogt et al. 1986).

Of all mature cell types, R-cells have the highest degree of disorder followed by F-cells. B-cells are only rarely affected by Leucaena-induced pathology. The pathogenesis can be subdivided into 3 stages. The first stage includes early nuclear and cytoplasmic effects before removal of heterochromatin. Stage 2 is characterized by the continuous decondensation of heterochromatin. The final, stage covers cell lysis. A summary of the nuclear and cytoplasmic alterations of the midgut gland cell types at these 3 stages is given in Table 2 .

\section{E-cells}

Each midgut gland-tubule is regenerated from a group of E-cells located at the distal closed end of the
Table 2. Penaeus monodon. Overview of major signs in successive stages of Leucaena-induced cytopathology. N: nuclear alterations, C: cytoplasmic signs

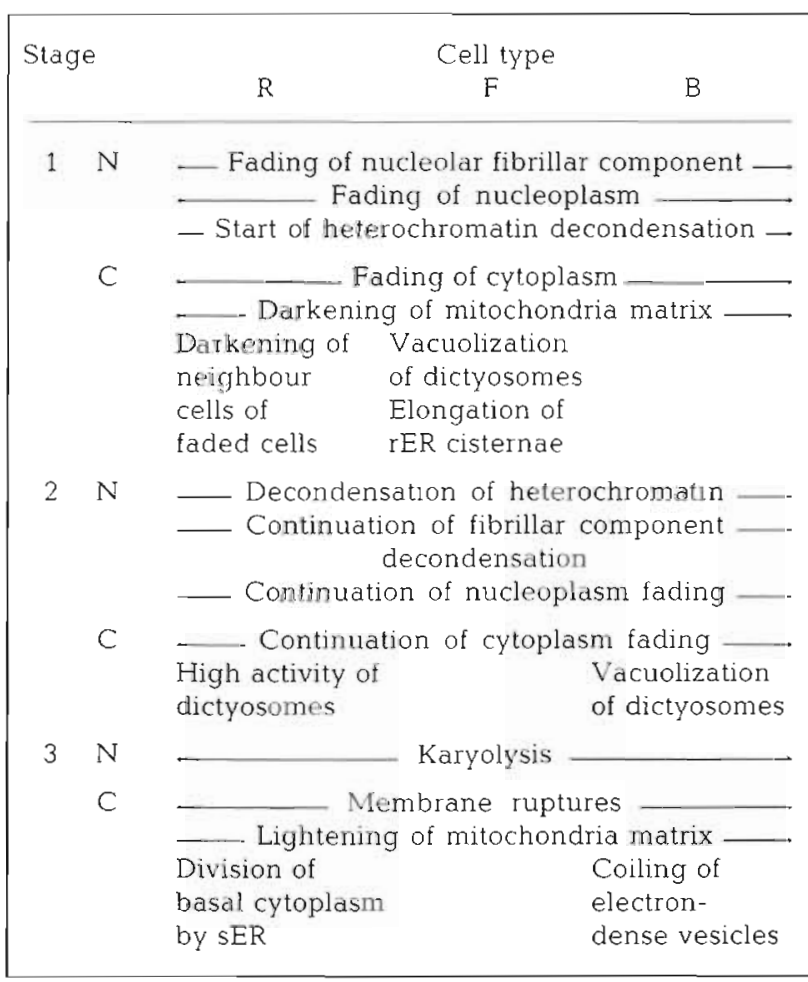

tubules. The E-cells only exhibit alterations comparable to the early pathological stages described below for R-cells: destruction of the fibrillar component of the nucleolus, fading of nucleoplasm and cytoplasm, and heterochromatin decondensation. 


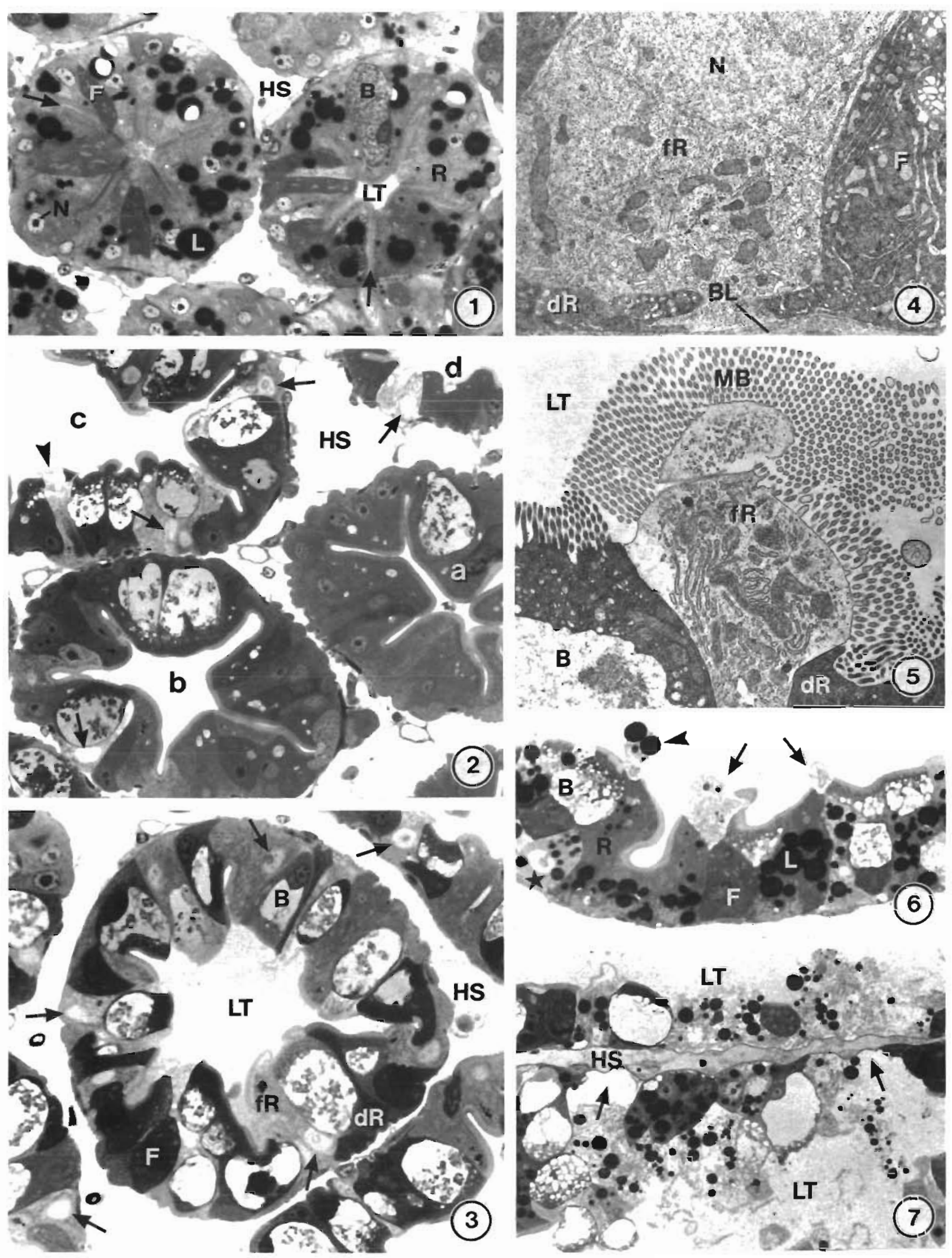




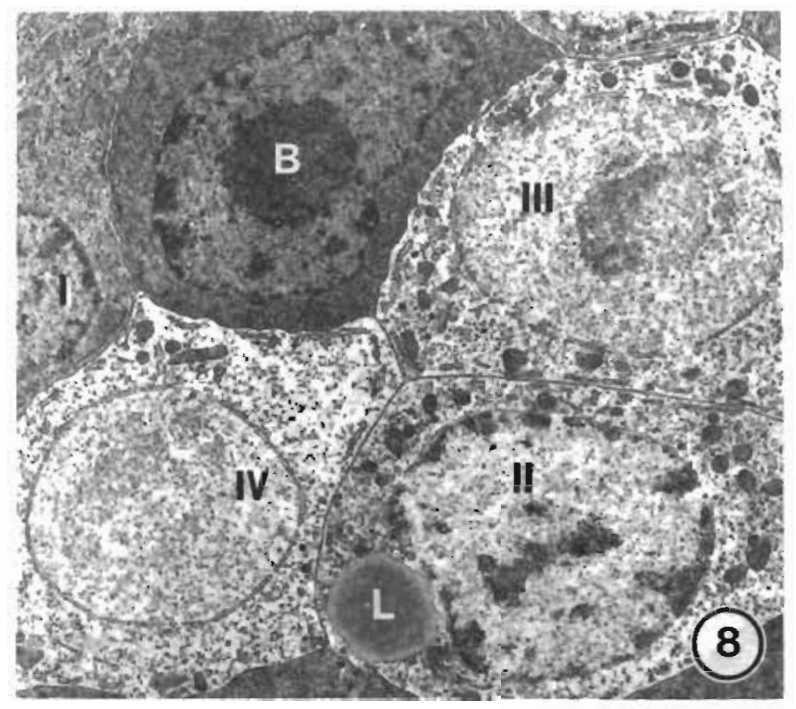

Fig. 8. Penaeus monodon. Leucaena-induced pathology of differentiating R-cells. (I) healthy cell; (II) early Stage 1; (III)

Stage 2; (IV) early lytic stage; (B) healthy B-cell $; \times 5150$

No obvious differences concerning the numbers or stages of mitotic cells were recorded between the diets or between the timepoints of sampling indicating that cell division is not affected by Leucaena feeding.

\section{Differentiating cells}

Differentiating cells display characteristics of injured R-, F- or B-cells, depending on which cell line they are affiliated to (Fig. 8).

\section{R-cells}

The R-cell (Figs. 9 to 30 ) is the most frequent cell type in the midgut gland of decapods. Its main functions are absorption and catabolism of nutrients, and storage of reserves (Loizzi 1971, Vogt et al. 1985).
At the start of the experiment ('normal' structure) Rcells of the postlarvae have relatively light to medium electron-dense cytoplasm and are organized with distinct polarity. The apical part of the cell, which is oriented towards the lumen of the tubule, bears a regular microvillous border. Underneath is a narrow organelle-free zone and a region dominated by concentrations of oval, moderately electron-dense mitochondria (Fig. 18).

The mid-upper part of the cell is characterized by large electron-light supranuclear autophagosomes containing heterogeneous material (Fig. 18). The cell nucleus is located in the mid-lower region. In sections, the nucleus displays 1 , or in rare cases 2 , compact nucleoli in which fibrillar component and granular component are interdigitated. Rather large heterochromatin clumps are concentrated along the nuclear envelope and around the nucleolus (Fig. 9). The basal part of the R-cell (directed towards the hemolymph space) is characterized by a tubular system of modified smooth endoplasmic reticulum (sER) which has direct contact with the extracellular space, by mitochondria accumulations and by a marked basal lamina (Fig. 23). Lipid inclusions, short cistemae of rough (r)ER, electron-dense lysosomes, peroxisomes and dictyosomes are scattered throughout the cytoplasm (Figs. 18 and 21). The dictyosomes consist of only few cisternae. The pronounced budding-off of rather electron dense Golgi vesicles from these organelles indicates high activity (Fig. 27).

In many R-cells of prawns fed for $4 \mathrm{~d}$ on Leucaena diets, the amount of electron light autophagosome-like vacuoles is considerably enhanced. In these cells, the product of dictyosomes is different from R-cells without autophagosome proliferation: rather electron-light vesicles containing electron dense granules are released (Fig. 28). These features are also found in nonpathological cells of Leucaena fed prawns after 11, 20 and $28 \mathrm{~d}$ (Fig. 21).

Figs. 1 to 7 Penaeus monodon. Leucaena-induced histopathology of midgut gland-tubules and cell extrusion. Figs. are light micrographs (LM) of midgut gland-tubule cross (CS) and longitudinal sections (LS), and electron micrographs (EM). Abbreviations are: (B) B-cell; (BL) basal lamina; (dR) darkened R-cell; (F) F-cell; (fR) faded R-cell; (HS) hemolymph space; (L) lipid; (LT) lumen of midgut gland-tubule; (MB) microvillous border; (N) nucleus; (R) R-cell. Figs. 1 to 3. Histopathology of midgut glandtubules. Fig. 1. Non-pathological tubules of postlarvae fed for $4 \mathrm{~d}$ on soaked Leucaena-diet. In cross section, the tubule epithelium displays several bulges and indentations. Arrows indicate indentations. CS, LM, $\times 420$. Fig. 2. Variability of pathology in a midgut gland after $28 \mathrm{~d}$ on unsoaked Leucaena-diet. The characteristic organization of the epithelium in bulges and indentations gradually disappears in injured tubules. Tubule (a) unchanged, (b) slightly altered, with one faded nucleus (arrow), (c) and (d) heavily altered, several cells with faded nuclei (arrows) or cells in lytic stage (arrowhead). CS, LM, ×480. Fig. 3. Pathologically altered tubule after $28 \mathrm{~d}$ feeding on unsoaked Leucaena-diet. R-cells are split up in faded and darkened populations. Arrows: faded nuclei. CS, LM, $\times 640$. Figs. 4 to 7 . Extrusion of cells from the epithelium. Fig. 4 . Separation of faded R-cell from the basal lamina by basolateral extensions of neightour cells. EM, $\times 8650$. Fig. 5 . Extrusion of faded R-cell. The space of the expelled cell in the epithelium is occupied by neighbour cells. EM, $\times 8350$. Fig. 6 . Extrusion of cells. Cells can be expelled before cell lysis is completed (arrows). The gaps created by expelled cells are simultaneously closed by neighbour cells. Arrowhead: extruded R-cell with large lipid deposits; : R-cell in Stage 2 of pathology with lipid droplets. LS, LM, $\times 650$. Fig. 7 . Ulcerations of midgut gland epithelium (arrows). LS, LM, $\times 430$ 


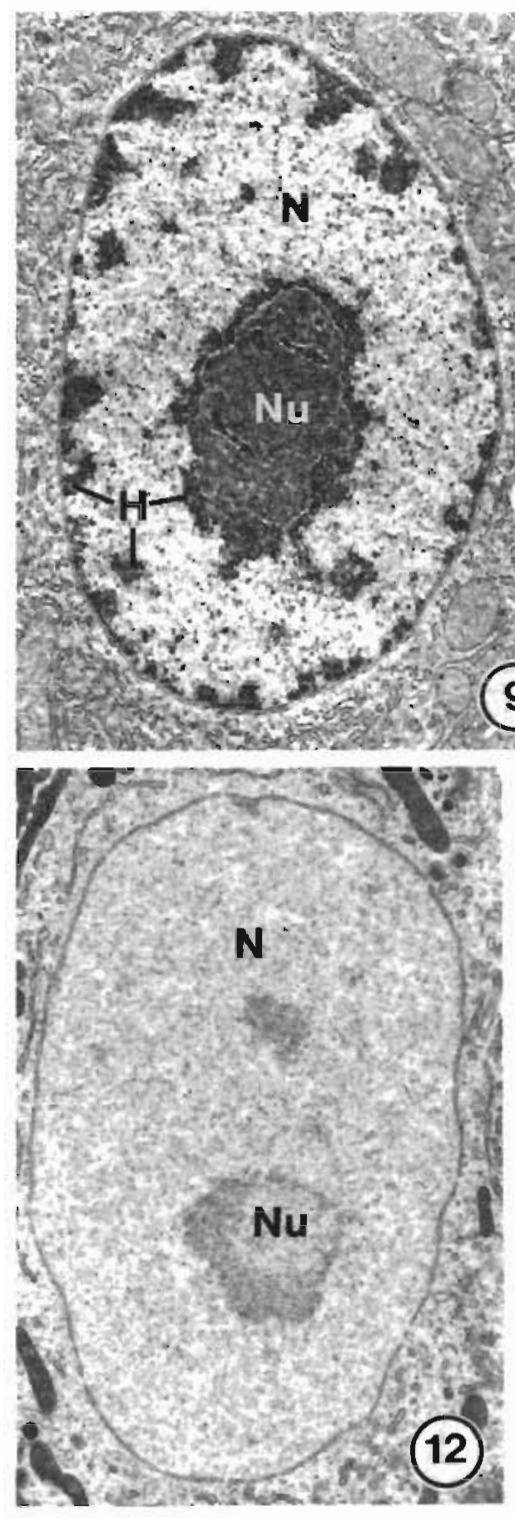

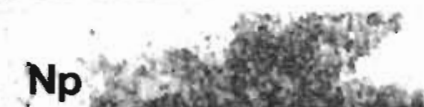

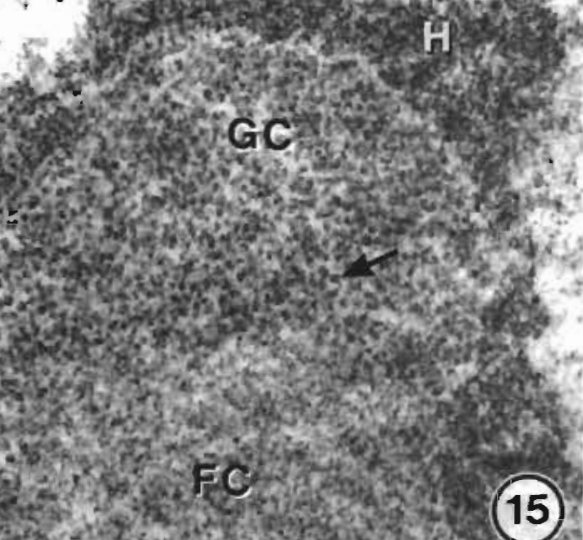

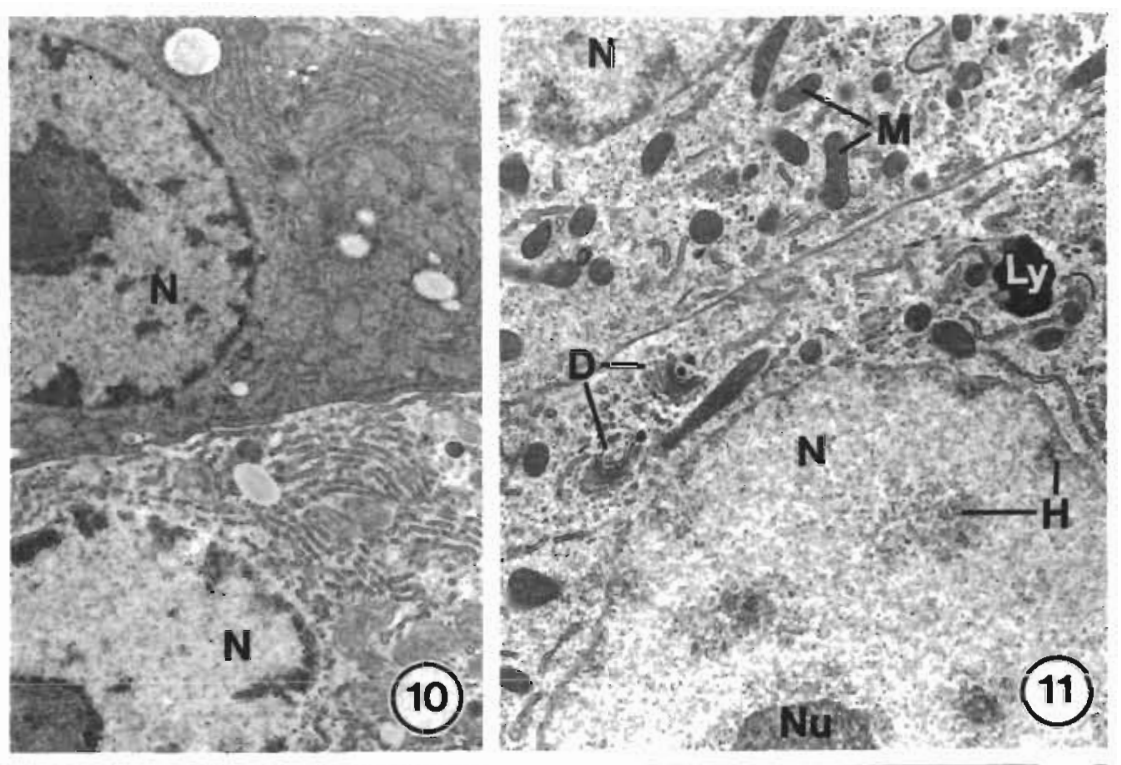

No

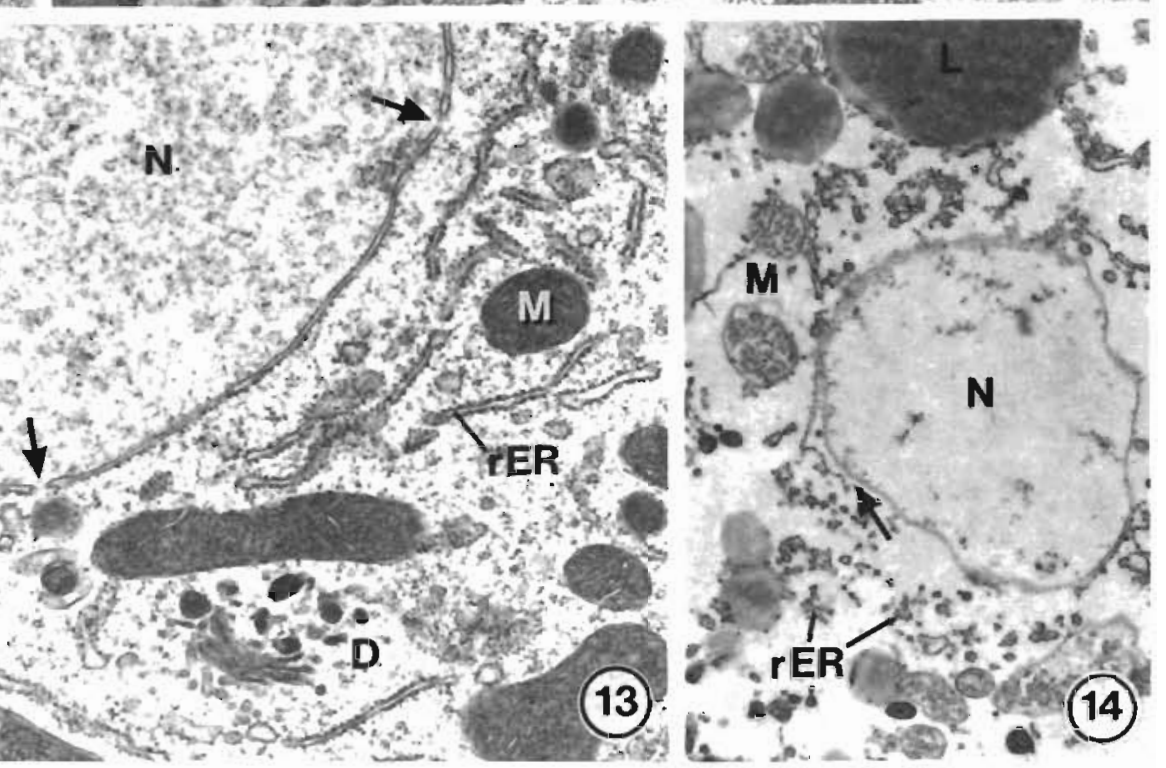

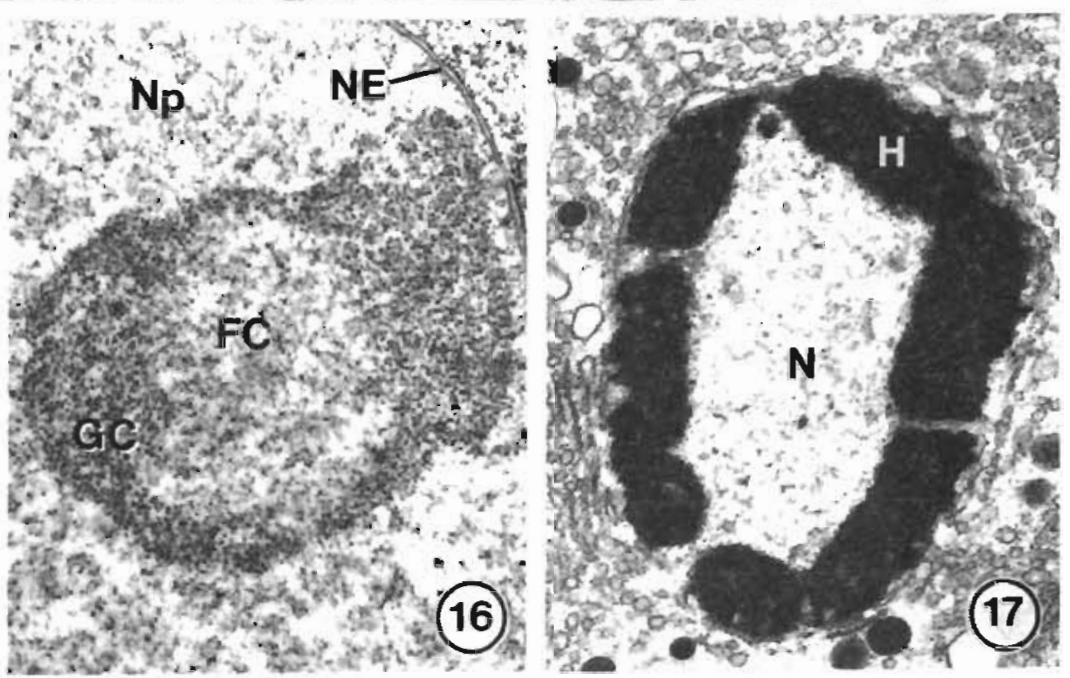


The first stage of pathology starts with fading of the fibrillar component of the nucleolus (Fig. 15), accompanied by a marked decrease in the electron density of nucleoplasm and cytoplasm (Fig. 10). At the same time, the electron density of the cytoplasm of neighbouring cells often increases (Fig. 10). During the process of cytoplasm fading, the mitochondrial matrices darken considerably (Figs. 19 and 25). Cells with faded nuclei and cytoplasm do not display electron-light autophagosomes.

In the second stage, the fibrillar component of the nucleolus and the heterochromatin of the cell nucleus are totally removed step-by-step (Figs. 11 to 13). The nuclear envelope, however, still exhibits its normal organization (Fig. 13). The plasmalemma and the intracellular membranes do not appear to be injured (Figs. 13 and 19). Lipid droplets still occur in the first and second stage of pathology and even in lytic cells (Fig. 14). Mostly, however, the lipid content is reduced in pathologically altered cells. Dictyosome activity is still high and even seems to be increased (Fig. 13). The basal sER, rER, lysosomes, peroxisomes, ribosomes, and the basal lamina display no conspicuous ultrastructural changes during pre-lytic cell alterations. The number of most of these cell organelles, however, particularly of the rER and of free cytoplasmic ribosomes, seems to decrease from the second stage on. In a few cells the apical plasmalemma is observed to disrupt already in Stage 2 (Fig. 20). Extrusion of cells may as well occur from Stage 2 (Fig. 6).

In the third stage, cells undergo lysis. Nucleoplasm and cytoplasm are totally emptied (Figs. 14 and 22), the nuclear heterochromatin and the fibrillar component of the nucleolus are completely removed (Figs. 14 and 16). The granular component of the nucleolus, in contrast, persists until lysis is completed (Fig. 16). Natural death of ageing cells results in opposite features of the nucleus, since the chromatin is condensed along the nuclear envelope (Fig. 17). The mitochondria, which are electron dense during the first and second stage become pale and are sometimes slightly dilated (Fig. 26). Dictyosomes no longer produce Golgi vesicles, and, in the late phase, their cisternae detach from each other (Fig. 29). Lysis of the cell base is often dominated by a peculiar development of the $S E R$, i.e. lateral protrusions of neighbouring sER tubules make contact with each other, thereby entrapping portions of the cytoplasm inclusive of the organelles. The basal cytoplasm is thus divided into numerous spheric bodies (Fig. 24). In the last period of the lytic stage, the plasmalemma and intracellular membranes disrupt and fragment (Fig. 22).

In addition to these common signs, some less frequent Leucaena-related effects can be detected in some unaffected or Stage 1 R-cells. These cells are randomly dispersed within tubules. The mitochondria of a few cells, for instance, contain electron-dense diffusely-limited inclusions in their matrices (Fig. 30). These mitochondrial inclusions are also visible in some F-cells. In other Stage 1 R-cells, huge and highly active dictyosomes are concentrated in clusters often associated with fibrillar material dispersed throughout the cytoplasm. From Day 20, small intracellular spaces can occur between the basolateral membranes of non-pathological adjacent cells. Rather rare observations are the proliferation of the outer membrane of the nuclear envelope in Stage 1 cells, the accumulation of electron dense material in sER and $\mathrm{rER}$, and the reduction of the microvilli to small balloon-like bubbles in otherwise intact R-cells as well as the inclusion of lipid in the nuclei at various stages of pathology.

Figs. 9 to 17. Penaeus monodon. Leucaena-induced alterations of R-cell nuclei and nucleus of cells which died naturally. Abbreviations are: (D) dictyosome; (FC) fibrillar component; (GC) granular component; (H) heterochromatin; (L) lipid; (Ly) lysosome; (M) mitochondrion; (N) nucleus; (NE) nuclear envelope; (Np) nucleoplasm; (Nu) nucleolus; (rER) rough endoplasmic reticulum. Figs. 9 to 14. Successive degeneration of the nucleus. Fig. 9. Non-pathological cell. Heterochromatin clumps are concentrated along the nuclear envelope and around the nucleolus; $\times 9400$. Fig. 10 . First steps of pathology (early Stage 1 ) showing fading of nucleoplasm and cytoplasm (cell at bottom) and darkening of cytoplasm in neighbour cell (top); $\times 7800$. Fig. 11 . Early Stage 2. Fading of the nucleoplasm has proceeded and the heterochromatin is partly decondensed. The cytoplasm has become electron light, the mitochondrial matrix is darkened and dictyosome activity seems to be enhanced; $\times 10500$. Fig. 12 . Late Stage 2. Heterochromatin and fibrillar component of the nucleolus have completely disappeared. The membranes of the nuclear envelope are still intact; $\times 8950$. Fig. 13 . Periphery of a late Stage 2 nucleus and adjacent cytoplasm. The nuclear envelope still displays its original structure with nuclear pores (arrows) and is studded with ribosomes. The mitochondria are electron dense, the dictyosomes appear highly active and the rER is structurally unchanged; $\times 17400$. Fig. 14. Lytic stage. Nucleoplasm and cytoplasm appear empty. The nuclear envelope disrupts and is broken down (arrow). The same is true for the membranes of the mitochondria and IER. Lipid reserves are still present in rather high amounts; $\times 8200$. Figs. 15 and 16 . Cytopathology of the nucleolus. Fig. 15. Early Stage 1. The fibrillar component (FC) is already considerably faded. The heterochromatin is slightly loosened. Arrow indicates pre-ribosome located in the granular component; $\times 36550$. Fig. 16 . Early lytic stage. The fibrillar component is almost completely removed, whereas the granular component appears cytologically unchanged; $\times 17600$. Fig. 17. Nucleus displaying complete chromatin condensation in expelled midgut gland cell after prolonged starvation. Chromatin condensation is also typical for natural cell death. Fig. serves as a contrast to the Leucaena-related heterochromatin decondensation displayed in Figs. 10 to $14 ; \times 14500$ 

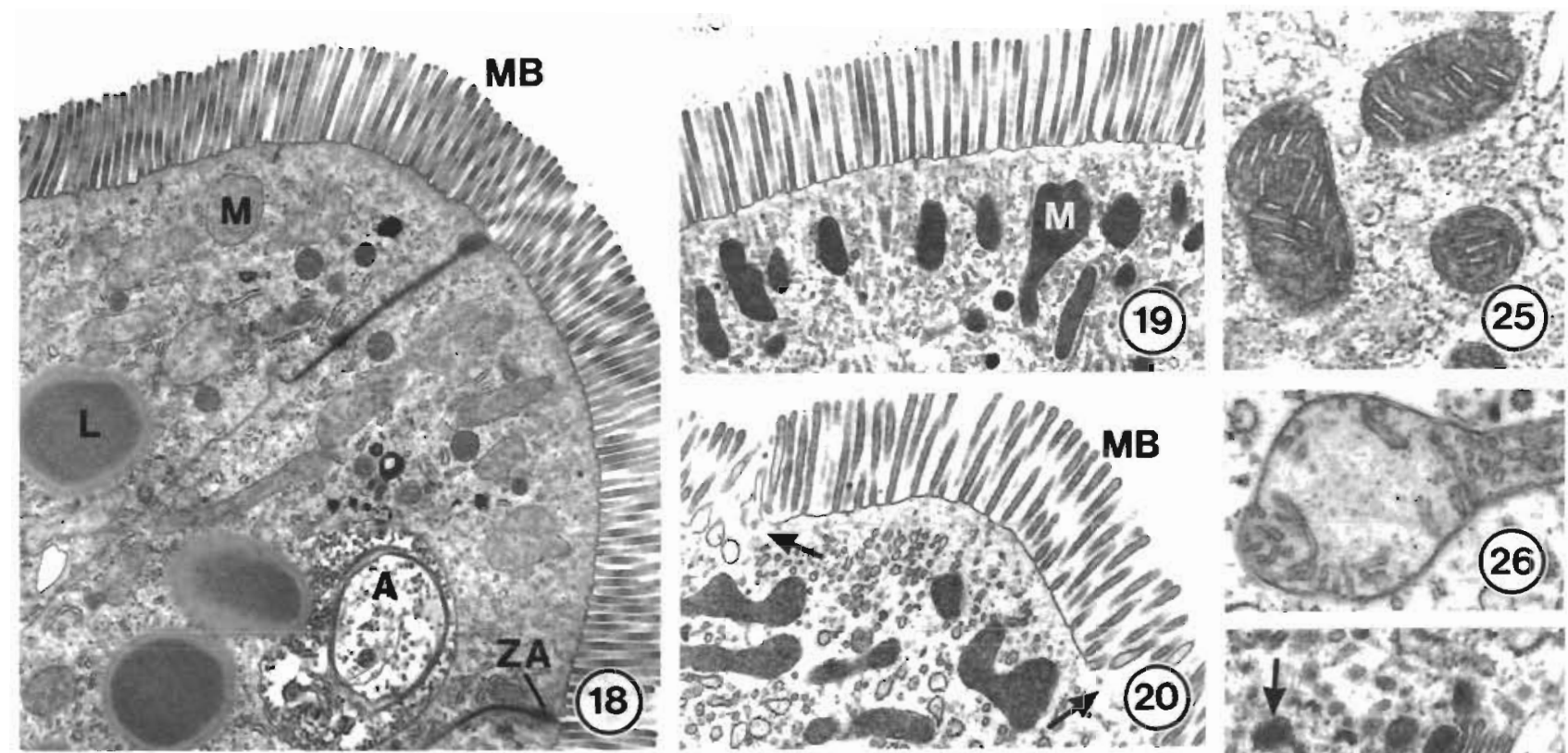

19)

(25)
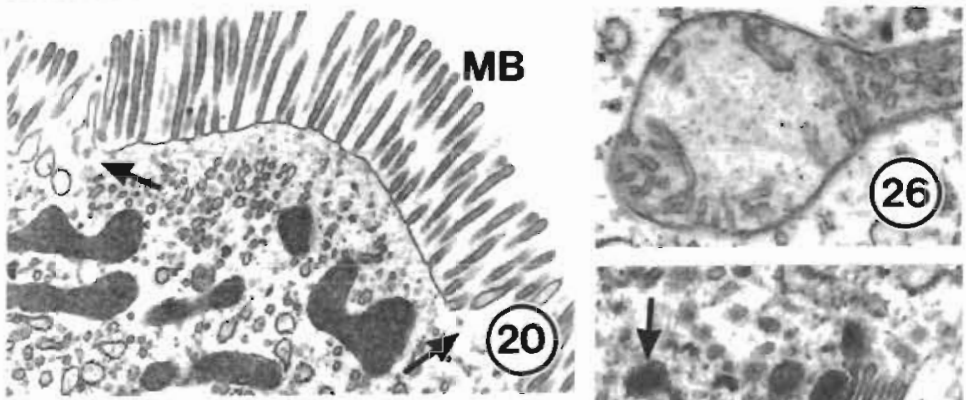

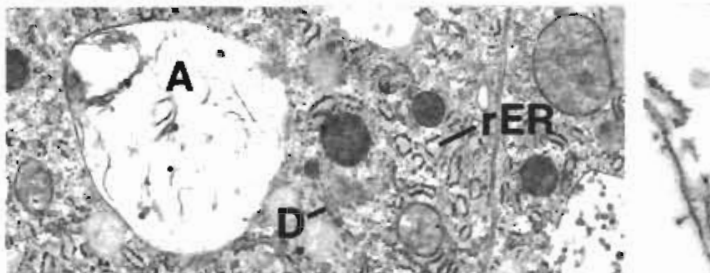

6.5.

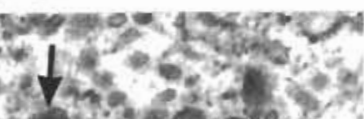

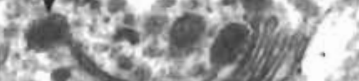
P H. 2. A 3 . 30 bily 0 (21)

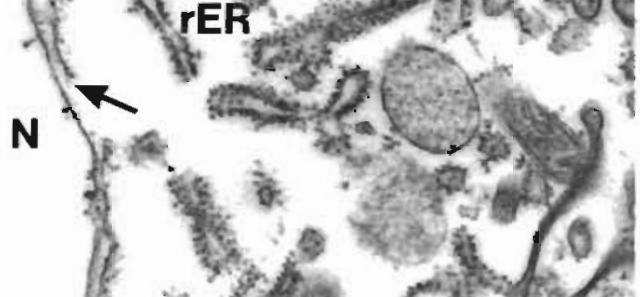
780

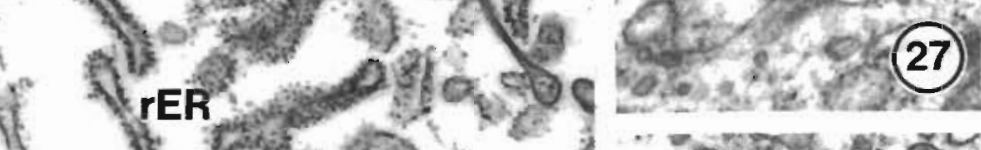

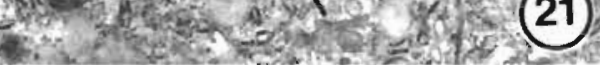
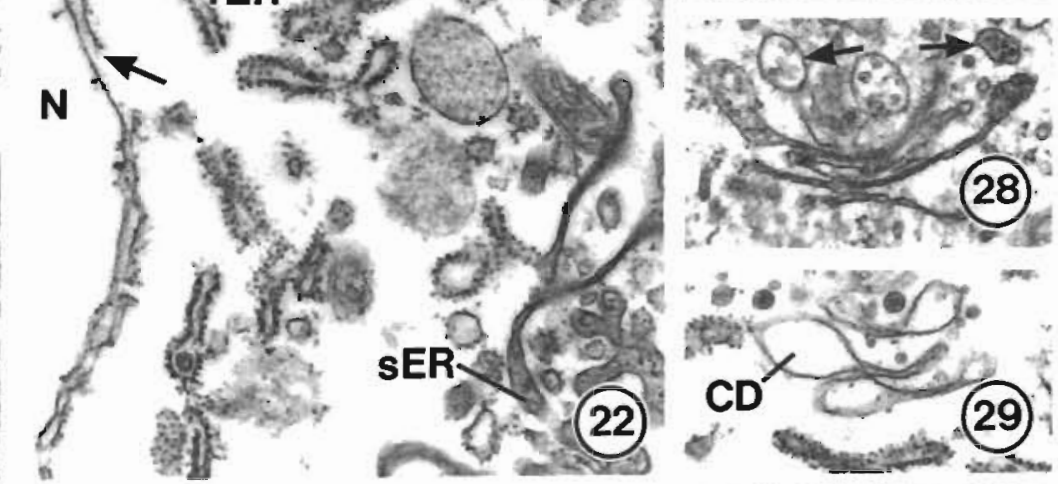

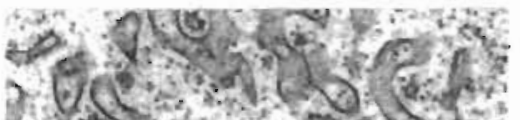

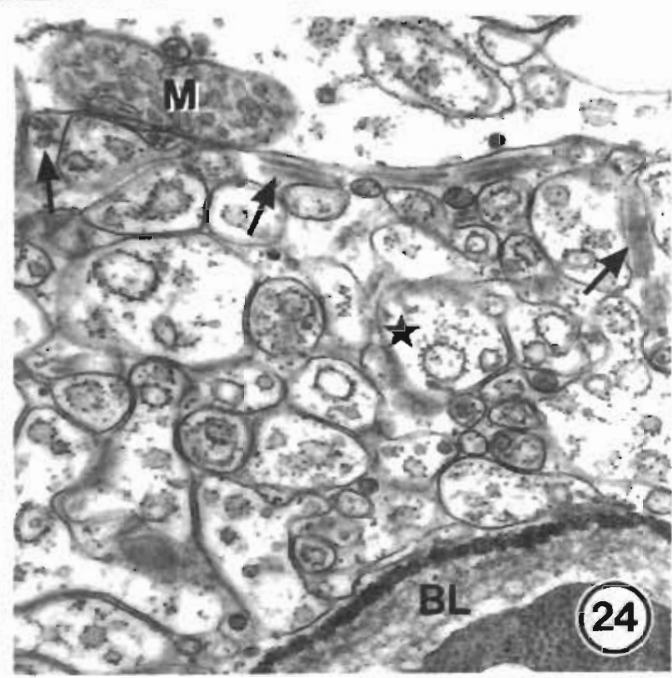

15.

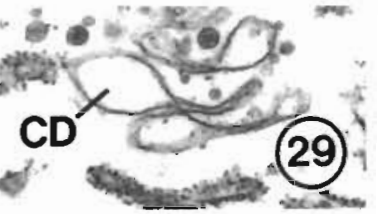

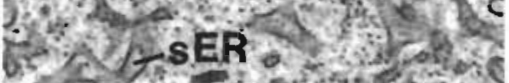

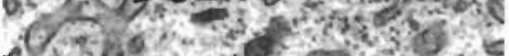

6.5. 3 . nus?

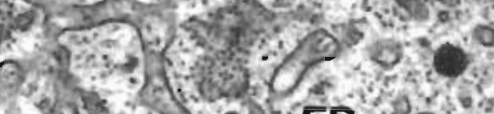

aj a o rER X

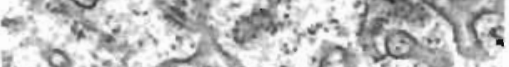

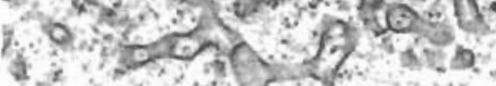

coseth BLI

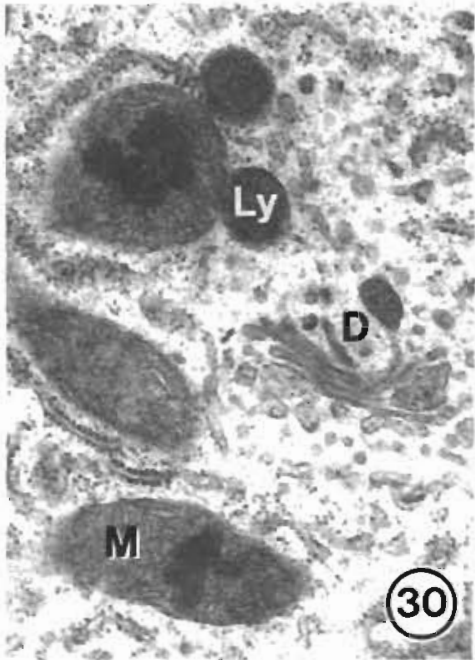


F-celis

The main function of F-cells (Figs. 31 to 39) is the synthesis of digestive enzymes (Vogt et al. 1989). In addition, F-cells seem to be involved in detoxification of heavy metals and organic compounds (Roldan \& Shivers 1987, Vogt 1987).

F-cells are not organized with such distinct polarity as R-cells. They bear a microvillous border at the tubular side (Fig. 33) and also a basal lamina, but the cell organelles are dispersed more homogeneously throughout the cytoplasm which has higher electron density compared to R-cells (Fig. 31). The nucleus is larger and bears heterochromatin clumps and a compact nucleolus (Fig. 31). The most characteristic features of F-cells are the high amount of vesicular rER and large dictyosomes (Fig, 31) composed of several moderately dilated cisternae (Fig. 35). In the period of enzyme synthesis transitional vesicles migrate from rER-cisternae to the cis-face of Golgi bodies (Fig. 37). The digestive enzyme containing vacuoles are formed on the trans-face (Fig. 36). These vacuoles have various electron densities (Fig. 33). They are located in small numbers near the Golgi bodies (Fig. 38) or along the microvillous border (Fig. 33). Mitochondria, lysosomes, autophagosomes, peroxisomes and the sER are structurally identical to their respective organelles in R-cells, but differ in frequency. Mitochondria, for instance, occur at lower numbers and the basal sER system consists of only a few tubules.

The pathological alterations are in most aspects similar to the R-cells. In the first stage, the electron density of the fibrillar component of the nucleolus, nucleo- plasm and cytoplasm decreases (Fig. 32). Thereafter, the matrices of the mitochondria become electron dense (Figs. 34 and 38). The dictyosomes, however, react differently to those in the $\mathrm{R}$-cells. The cisternae detach from each other already in Stage 1 and form spherical bodies (Fig. 39). In the early period of disintegration, the Golgi bodies may still be functioning since enzyme vacuoles are often located near the organelles. Transport vesicles between the transitional elements of the rER and the spherical cisternae of the dictyosomes are even found in completely vacuolized dictyosomes (Fig. 39). The rER starts to form cisternae of medium length during the first stage of pathology (Fig. 38). This tendency continues in the following period.

The second and third stages of pathology are similar to R-cells except for the curious alterations in the basal sER which does not occur in F-cells.

$$
\text { B-cells }
$$

Until now, none of the functions of B-cells (Figs. 40 to 50) suggested in literature have been convincingly proven. They are interpreted either as mature F-cells (Caceci et al. 1988) or as digestive cells (Al-Mohanna \& Nott 1986). According to my own investigations, the $\mathrm{B}$-cell is an independent cell-line which is not involved in any of the functions mentioned (Vogt 1985). Its cytological structures indicate that material of unknown identity is resorbed from the lumen of the gland by pinocytosis and thereafter degraded in the cell. Non-utilizeable parts of degraded material are obviously deposited in a central vacuole and the cell is

Figs. 18 to 30. Penaeus monodon. Leucaena-induced alterations of cytoplasmic compartments in R-cells. Abbreviations are: (A) autophagosome; (BL) basal lamina; (CD) cisterna of dictyosome; (D) dictyosome; (L) lipid; (Ly) lysosome; (M) mitochondrion; (MB) microvillous border; (N) nucleus; (P) peroxisome; (rER) rough endoplasmic reticulum; (sER) smooth endoplasmic reticulum; (ZA) zonula adhaerens. Figs 18 to 20. Cell apex. Fig. 18. Apices of non-pathological cells showing a regular microvillous border. Neighbour cells are apically attached to each others by zonulae adhaerentes; $\times 8100$. Fig. 19. Apex of early Stage 2 -cell. The microvilli are still intact, the mitochondria are electron dense; $\times 7900$. Fig. 20. Apex of late Stage 2 cell. The apical plasmamembrane disrupts (arrows) - this phenomenon normally occurs in lytic cells, sometimes, however, it can be observed in earlier pathological stages; $\times 9100$. Figs. 21 and 22 . Middle cell region. Fig. 21 Cell organelles of non-pathological cells after $20 \mathrm{~d}$ on soaked Leucaena diet. The cells display the same cytological features as after $4 \mathrm{~d}$ on Leucaena. Note the proliferation of electronlight autophagosomes and the rather electron-light mitochondria; $\times 12100$. Fig. 22. Late lytic cell. Cytoplasm and nucleoplasm appear completely emptied. The outer membrane of the nuclear envelope fragments (arrow). rER and sER are not yet visibly altered; $\times 26650$. Figs. 23 and 24 . Cell base. Fig. 23 . Non-pathological cell. The base is characterized by a tubular network of sER. Arrows indicate the dimension of the basal lamina which consists of an electron-dense globular structured and a less electrondense fibrillar layer; $\times 23900$. Fig. 24 . Late lytic cell. The basal cytoplasm is completely divided into medium-sized bubbles by a transformation of the sER. The membranes of the cytoplasmic bubbles originate from the sER membranes. Arrows indicate longitudinal and cross sections of tube-like fibrillar structures which occasionally occur in the sER lumen of non-pathological cells, and here indicate the remnants of the former sER lumen. $\star$ : cytoplasm portion including rER-vesicle; $\times 20050 . \quad$ Figs. 25 and 26. Mitochondria. Fig. 25. Electron-dense mitochondria in a Stage 2 cell; $\times 29$ 500. Fig. 26. Partial swelling of pale mitochondrion in lytic cell; $\times 17900$. Figs. 27 to 29. Dictyosomes. Fig. 27. Dictyosome in non-pathological cell without autophagosome proliferation synthesizing electron-dense Goígi vesicles (arrow); $\times 29700$. Fig. 28. Dictyosome in non-pathological cell with autophagosome proliferation budding off larger electron-light Golgi vesicles with small granules (arrows); $\times 31850$. Fig. 29. Dictyosome in late lytic cell showing cisternae which detach from each other; $\times 21700$. Fig. 30. Less frequent Leucaena-related alteration. Electrondense inclusions in mitochondria of non-pathological cell; $\times 23400$ 


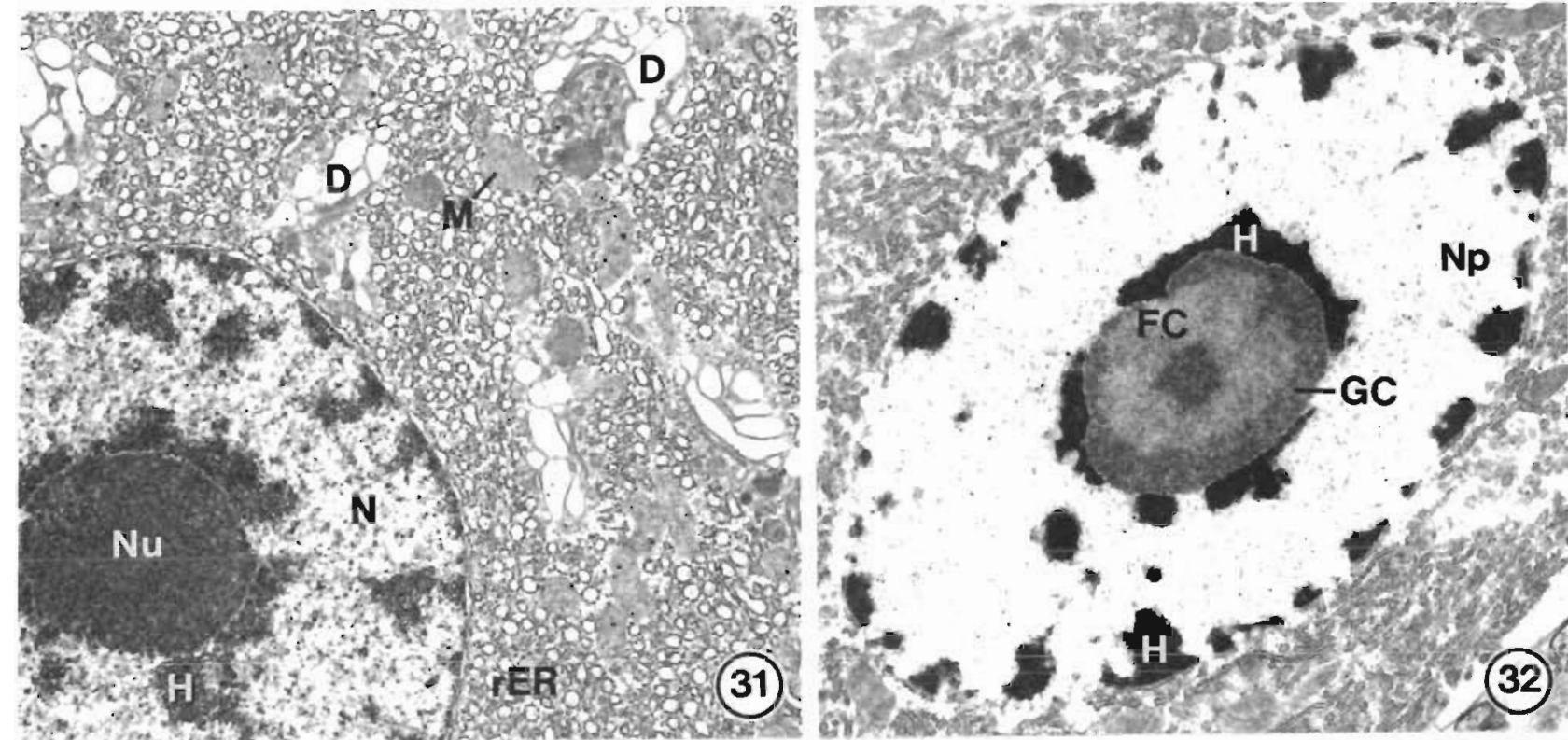

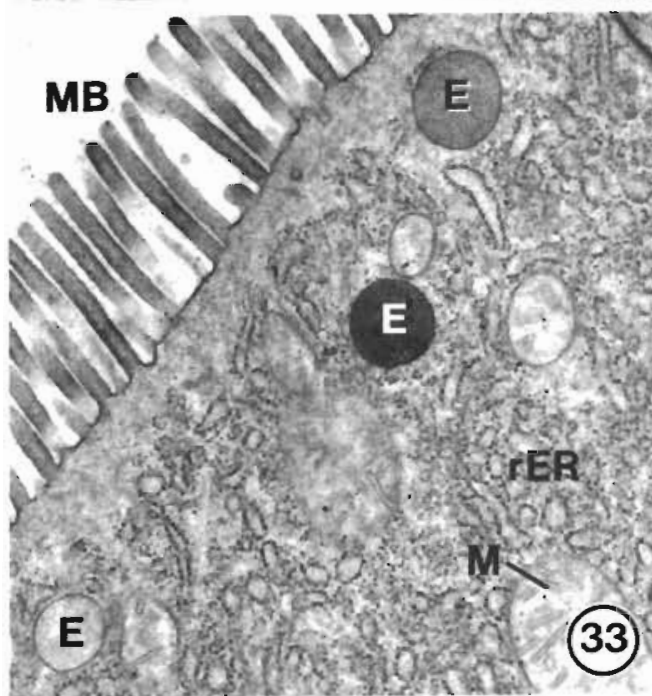

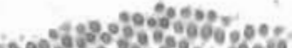

\%

Pำ

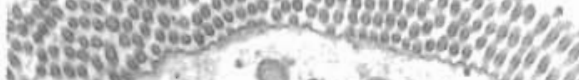
12.

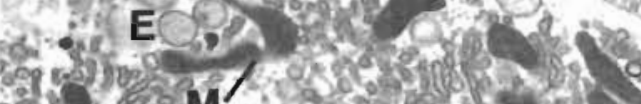
(5)

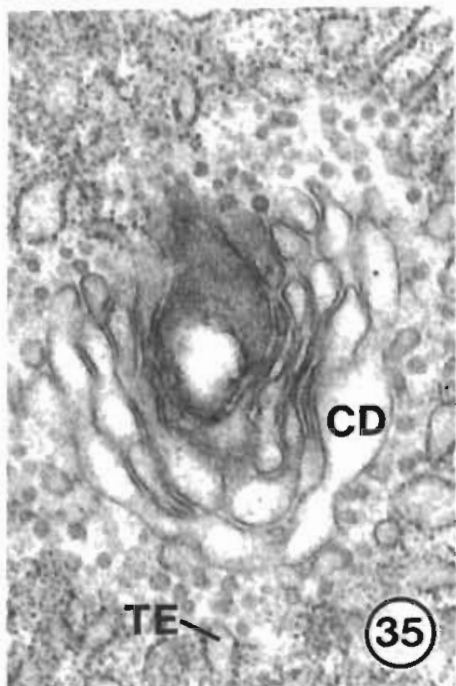

5.

in D
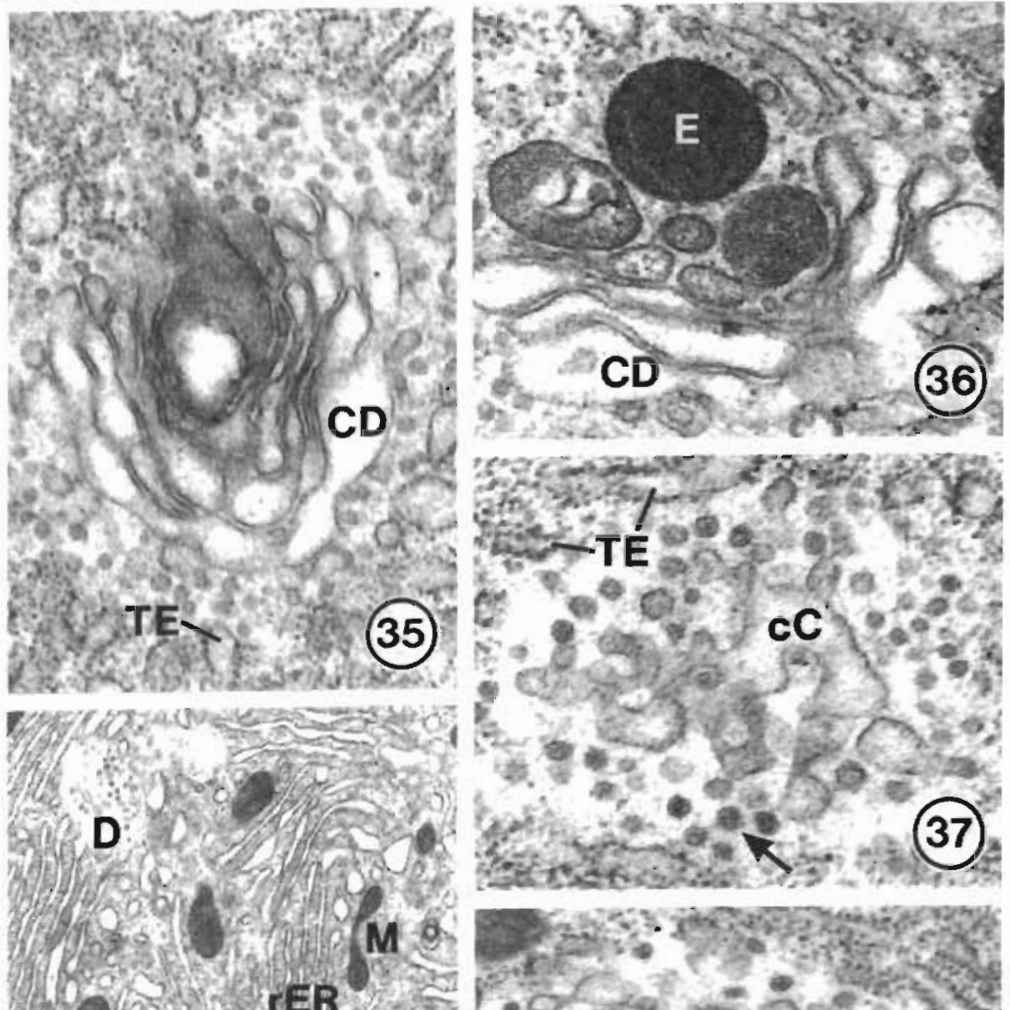

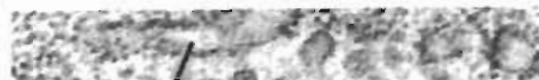

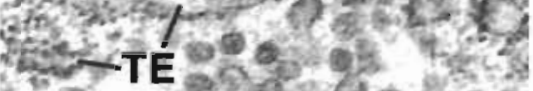

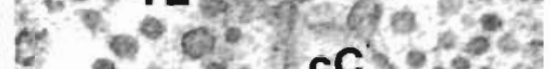

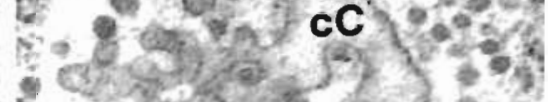

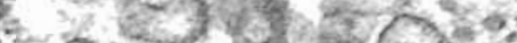

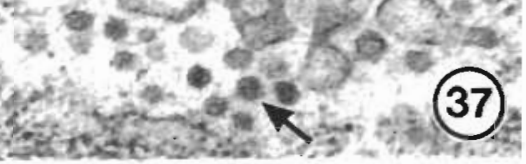

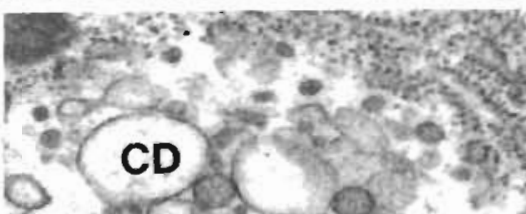

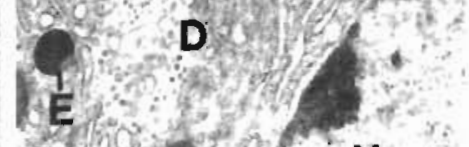

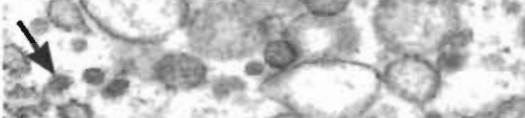
(19) 3002 (38

(38) 3 (39) $^{2}$ (3) 
thus transformed from an immature to a mature stage. The mature cells are extruded into the tubule lumen during a certain period of the digestive cycle. The significance of this process is not yet clear.

Three regions can be distinguished in mature $B$ cells: apical, central and basal (Fig. 40). The apical part is characterized by a slightly irregular microvillous border, by numerous pinocytotic channels, pinocytotic vesicles and small electron-dense vesicles, by few mitochondria, small amounts of rER and by very few dictyosomes (Fig. 48). The electron-dense vesicles seem to fuse with both pinocytotic vesicles and medium-sized vacuoles (Fig. 43), the latter originating from multiple fusion of pinocytotic vesicles. These medium-sized vacuoles are then integrated into the central vacuole. The cytoplasm of non-pathological Bcells varies from moderately electron-dense in young cells to extremely electron-dense in mature cells. In parallel with the formation of the central vacuole, the cytoplasm darkens. Depending on the developmental stage of the B-cell, the mid-region is dominated by several vacuoles of varing size, or by a single central vacuole (Fig. 40). Most vacuoles contain heterogeneous material. Laterally, the central vacuole is surrounded by a small rim of cytoplasm with only a few cell organelles. The basal cytoplasm extends from the central vacuole to the basal membrane facing the hemolymph space. This region contains the irregularly limited cell nucleus which, in mature cells, mostly has a rather small compact nucleolus, large amounts of $r E R$ organized in long cisternae (Fig. 40), dictyosomes composed of several straight and elongated cisternae (Fig. 44), mitochondria and few sER tubules. Mature B-cells lose their contact with the basal lamina.

Comparable to the other cell types, the first pathological alterations of B-cells are fading of the nucleolar fibrillar component, nucleoplasm and cytoplasm (Fig. 41), followed by complete decondensation of the nuclear heterochromatin (Fig. 42). Similar to F-cells, the cisternae of the Golgi-bodies vacuolize, but only from the second stage of pathology (Fig. 45). Alterations of the mitochondrial matrices are not as obvious as in other cell types, since they vary considerably during the normal process of maturation. The other cell organelles are structurally unchanged in the pre-lytic stages (Figs. 48 and 49).

Cell lysis occurs in a manner similar to that for $\mathrm{R}$ - and F-cells (Figs, 42, 46, 47 and 50). Surprisingly, the small electron-dense vesicles at the cell apex seem to be the most stable cell compartments. They often exhibit coiled shapes indicating division and multiplication rather than destruction (Fig. 47).

\section{DISCUSSION}

\section{Leucaena-related pathology in vertebrates}

Until now, pathological signs of Leucaena-related disorders have been reported only in mammals: e.g. lingual epithelial ulcerations in cattle (Holmes et al. 1981); focal lesions of the oesophagus and necrotic papillae in the reticulo-rumen of goat (Megarrity \& Jones 1983); thinning and atrophy of the epidermis of mouse (Montagna \& Yun 1963); perforation of the uterus of rat resulting in fetal deformities (Dewreede \& Wayman 1970); follicular cell hyperplasia and colloid accumulation in thyroid glands of calves (Holmes et al. 1981) mice and rats (Hegarty et al. 1979); focal replacement of eye-lens fibres by globular bodies in calves (Holmes et al. 1981)

At the electron microscopic level, the only mimosineinduced alterations are published by von Sallmann et al. (1959). They reported an increase in cell size, swelling of the mitochondria, distentions of the rER and clumps of electron dense material in the nucleolus of rat eye-lens equatorial cells. On their micrographs these 'clumps' are scattered around an electron light

Figs. 31 to 39. Penaeus monodon. Leucaena-induced cytopathology of F-cells. Abbreviations are: (cC) cis-cisterna of dictyosome; (CD) cisterna of dictyosome; (D) dictyosome; (E) digestive enzyme containing vacuole; (FC) fibrillar component; (GC) granular component; (H) heterochromatin; (M) mitochondrion; (MB) microvillous border; (N) nucleus; (Np) nucleoplasm; (Nu) nucleolus; (rER) rough endoplasmic reticulum; (TE) transitional element of rER. Figs. 31 and 32. Nucleus. Fig. 31. Nucleus and adjacent cytoplasm of non-pathological cell. The nucleus displays heterochromatin clumps and a compact nucleolus. Large dictyosomes and vesiculated $r E R$ are pre-dominant features of the cytoplasm; $\times 9400$. Fig. 32 . Stage 1 nucleus with faded nucleoplasm, fibrillar component and cytoplasm. The amount of heterochromatin is not yet reduced; $\times 10500$. Figs. 33 and 34 . Cell apex. Fig. 33 . Nonpathological cell with a regular microvillous border and digestive enzyme containing vacuoles of low, medium and high electron density; $\times 19550$. Fig. 34. Stage 2 cell with electron-dense mitochondria and vacuolized dictyosomes. Enzyme vacuoles are still present and all membrane systems appear unchanged; $\times 8300$. Figs, 35 to 39 . Dictyosomes. Fig. 35. Dictyosome of nonpathological cell consisting of elongated cisternae which are repeatedly interlaced; $\times 28250$. Fig. 36 . Trans-face of dictyosome from non-pathological cell displaying enzyme vacuole formation by fragmentation of the trans-cisterna; $\times 42$ 000. Fig. 37 . Cis-face of unchanged dictyosome from early Stage 1 cell. Transitional vesicles (arrow) bud off from the transitional elements and migrate to and fuse with the cis-cisterna of the dictyosome; $\times 42300$. Fig. 38. Middle region of Stage 1 cell displaying unchanged (bottom) and vacuolizing (top) dictyosomes. Cytoplasm and nucleoplasm are slightly faded, the mitochondria are darkened and the rER forms medium length cisternae; $\times 7000$. Fig. 39. Vacuolization of dictyosome in late Stage 1 cell. The Golgi cisternae are completely transformed to spheric bodies. Transitional vesicles are still present (arrow); $\times 29100$ 

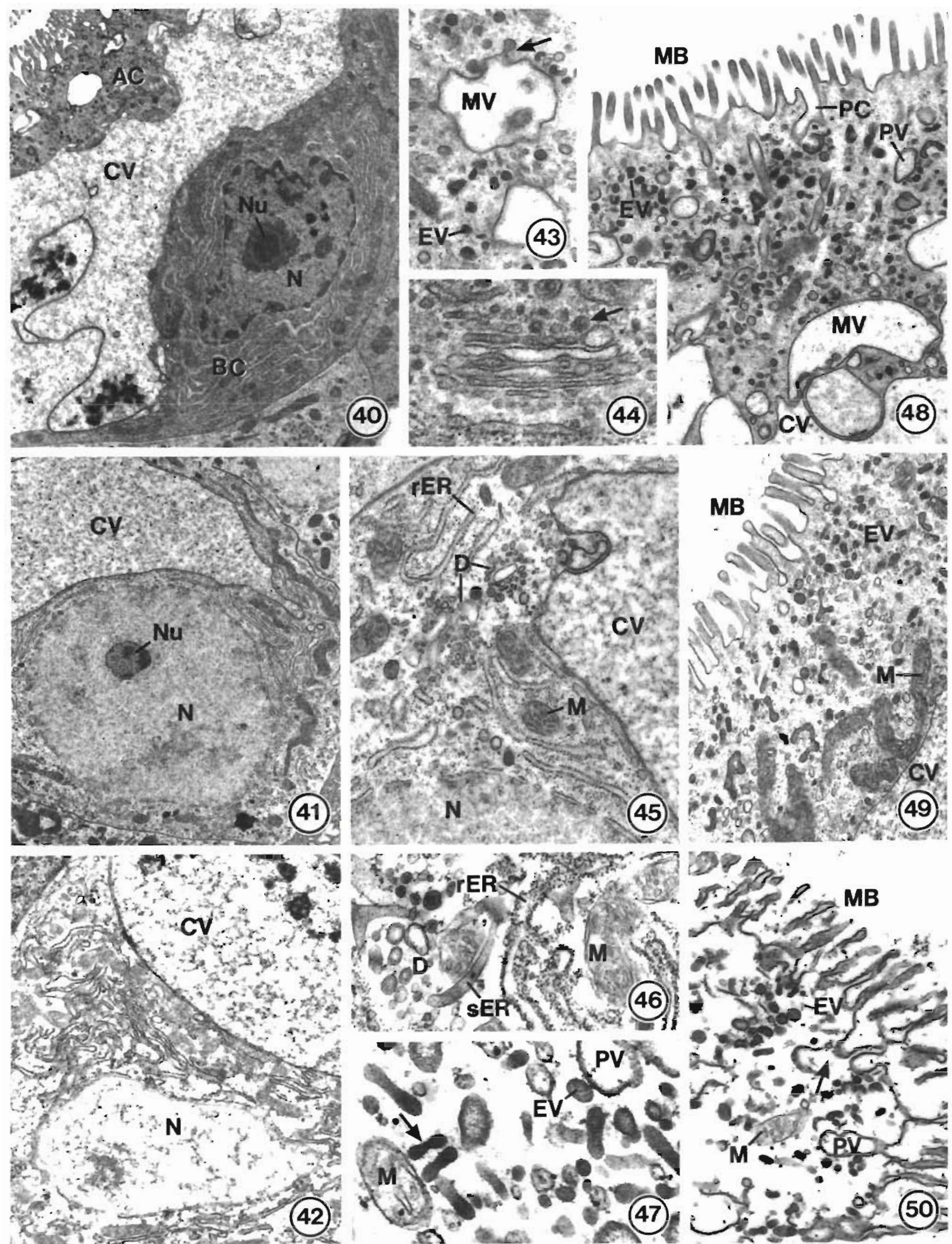

(46)
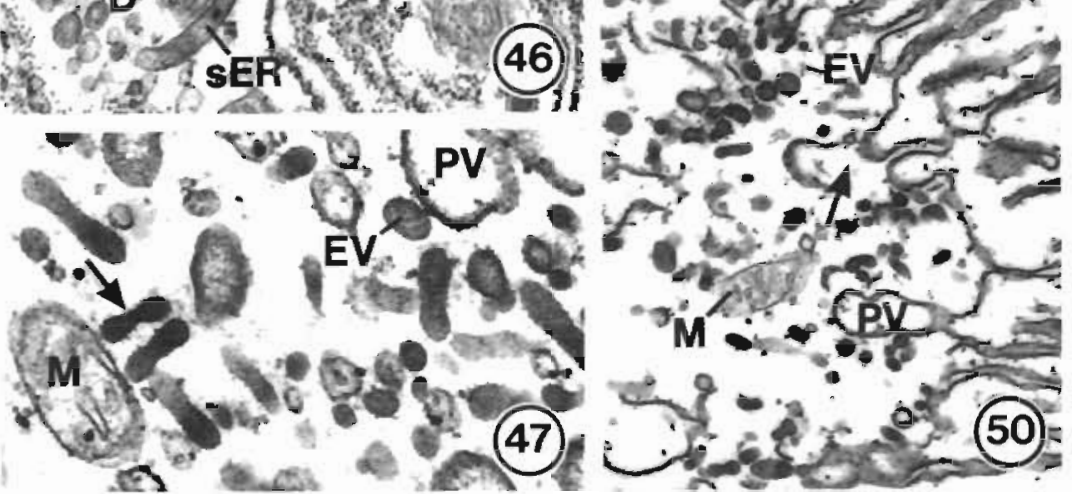

R sto (42) er acto 
core resembling the arrangement of the granular component around the faded fibrillar component in Stage 1 of Penaeus monodon pathology.

\section{Proposed biochemical mechanisms of mimosine toxicity in vertebrates}

There is general agreement that Leucaena-related disorders are caused by mimosine or its degradation products such as DHP (dihydroxypyridine). DHP is only slightly cytotoxic, but it is a potent goitrogen leading to thyroid hypertrophy (Hegarty et al. 1964). Several hypotheses concerning the biochemical mechanisms of mimosine-related cell injury have been suggested: (1) inhibition of metalloenzymes through chelation of metals (Chang 1960); (2) inhibition of enzymes which require pyridoxalphosphate as a co-enzyme (Lin et al. 1962); (3) inhibition of DNA-synthesis (Tsai \& Ling 1971); (4) impairment of the cytoskeleton (Hegarty et al. 1964).

There is no doubt that mimosine is a potent chelator. Tsai \& Ling (1973) evaluated that mimosine forms highly stable chelates with $\mathrm{Fe}^{3+}>\mathrm{Al}^{3+}>\mathrm{Cu}^{2+}$, and rather unstable chelates with $\mathrm{Pb}^{2+}>\mathrm{Zn}^{2+}, \mathrm{Ni}^{2+}>\mathrm{Co}^{2+}$ $>\mathrm{Ca}^{2+}$ and $\mathrm{Mg}^{2+}$. They concluded from their experiments that the 3-hydroxyl and 4-oxo groups act as the chelating sites in $\mathrm{Fe}^{3+}$ and $\mathrm{Al}^{3+}$ chelates.

Pyridoxal phosphate is involved in a wide range of metabolic functions since it acts as a co-enzyme in aminotransferases, decarboxylases and several lyases and synthetases. Particularly in the metabolism of amino acids, pyridoxal phosphate holds a central position. Its inhibition may thus lead to a wide variety of pathological disorders. Lin et al. (1962) proposed a model for the explanation of pyridoxal phosphate inhibition by presuming that the mimosine side chain and the aldehyde group of pyridoxal phosphate form a pyridone-tetrahydropyridine unit.
Inhibition of DNA-synthesis has been observed in tissue cultures of sheep-skin slices (Ward \& Harris 1976), cell cultures (Tsai \& Ling 1971, Hegarty et al. 1978), and in the fungus Sclerotium rolfsii (Serrano et al. 1983). By using a wide range of chemically modified mimosine-related molecules, Ward \& Harris (1976) and Hegarty et al. (1978) identified the 3-hydroxyl and 4oxo moiety of the pyridine ring as the cytotoxic component. This is in accordance with the model of mimosine chelation of Tsai \& Ling (1973). Ward \& Harris (1976) argued for a direct inhibition of DNA-synthesis by mimosine, while Hegarty et al. (1978) assumed that depression of DNA-synthesis reflects other cytotoxic effects rather than a direct inhibition.

Detrimental influences of Leucaena or mimosine on elements of the cytoskeleton in animals and plants are only reported in relation to mitosis. For example, degeneration of cells in the mitotic region of hair follicle bulbs and consequent retrogression of the follicle bulbs were observed in mouse (Montagna \& Yun 1963) and sheep (Reis et al. 1975). Moreover, mitotic disturbances led to growth inhibition in various animal tumor cells (Tsai \& Ling 1971, DeWys \& Hall 1973, Prabhakaran et al. 1973). The capability of mimosine to act as mitose-inhibiting agent was also demonstrated in plants by Pritchard \& Court (1968). They found that cell division of root tips of Vicia faba is arrested in metaphase.

\section{Leucaena-induced cytopathology in Penaeus monodon}

Three complexes of Leucaena-related cytopathology in Penaeus monodon postlarvae must be discussed: (1) early injuries to the nucleus; (2) early injuries to the cytoplasm and its organelles; and (3) pathologic alterations related to final cell lysis. In this experiment it was not directly proven that mimosine is the cytotoxic

Figs. 40 to 50. Penaeus monodon. Leucaena-induced cytopathology of B-cells. Abbreviations are: (AC) apical complex; (BC) basal cytoplasm; (CV) central vacuole; (D) dictyosome; (EV) electron dense vacuole; (M) mitochondrion; (MB) microvillous border; (MV) medium-sized vacuole; (N) nucleus; (Nu) nucleolus; (PC) pinocytotic channel; (PV) pinocytotic vesicle; (rER) rough endoplasmic reticulum; (sER) smooth endoplasmic reticulum. Figs 40 to 42 . Nucleus and cell base. Fig. 40. Non-pathological cell showing the typical organization into 3 regions: apical complex, central vacuole area and basal cytoplasm with the cell nucleus: $\times 5580$. Fig. 41 . Stage 2 cell. Nucleoplasm and cytoplasm are faded and the heterochromatin is almost completely decondensed. $\times 4900$. Fig. 42. Lytic stage nucleus characterized by rupture of the membranes of the nuclear envelope; $\times 8800$. Figs. 43 to 47. Cell organelles. Fig. 43. Non-pathological cell. Arrow indicates the fusion of electron-dense vesicles and medium-sized vacuoles; $\times 18500$. Fig. 44. Dictyosome of non-pathological cell which is composed of few elongated, narrowly stacked cisternae and buds off small electron-dense Golgi vesicles (arrow); $\times 43$ 150. Fig. 45. Stage 2 cell. The dictyosomes vacuolize while the other cell compartments seem largely unchanged; $\times 14850$. Fig. 46. Early lytic cell with vacuolized dictyosome and electron-light mitochondrion. rER and sER still seem unchanged; $\times 23600$. Fig. 47 . Late lytic cell with electron-dense vesicles which are often elongated and coiled at the ends resembling division of the compartment (arrow); $\times 42200$. Figs. 48 to 50. Cell apex. Fig. 48 . Early Stage 1 cell with slightly faded cytoplasm. Characteristic features of B-cell apices such as pinocytotic channels, pinocytotic vesicles, electron dense vesicles and medium sized vacuoles appear unaffected; $\times 11700$. Fig. 49 . Stage 2 cell with proceeded fading of the cytoplasm and darkened mitochondria; $\times 14950$. Fig. 50. Lytic cell showing disrupting and fragmentating microvilli, pinocytotic channels and vesicles (arrow); $\times 15050$ 
agent. However, the bulk of information published for vertebrates fed either with Leucaena or mimosinecontaining diets indicates a high degree of similarity between observed cytopathological alterations in Penaeus monodon and the clinical signs in mammals caused by mimosine or its degradation products. A further argument derives from the fact that the mimosine-reduced Leucaena diet resulted in less severe cytopathology.

Early injuries to the cell nucleus. Primary alterations of the nucleus are common after infections with nuclear viruses (e. g. Lightner et al. 1983). Primary attacks of xenobiotics directed toward the cell nucleus, however, are less frequent than on membrane systems or cell organelles. Triebskorn (1989), for instance, reported on fading of nucleopiasm and moderate reduction of heterochromatin in digestive tract mucus cells of the snail Deroceras reticulatum after carbamate intoxication.

The most significant and sensitive nuclear sign after Leucaena feeding in Penaeus monodon is the alteration of the fibrillar component of the nucleolus. The fibrillar component is the site of the nucleolus organizer region (NOR), where the primary transcripts of rRNA are synthesized (Stahl 1982). These transcripts are then packaged with proteins derived from the cytoplasm and processed by various enzymes. Some of the processing products are accumulated as pre-ribosomes in the granular component of the nucleolus. The nucleoli represent one of the most active parts of the cell and play a considerable role in human pathology. Daskal (1979) and Ghadially (1988) give numerous examples of nucleolar hypertrophy, degranulation, fragmentation or segregation under experimental or pathological conditions. Enhancement of RNA and protein synthesis, for instance, leads to nucleolus hypertrophy (Ghadially 1988). In Leucaena-fed Penaeus monodon postlarvae, the fibrillar component undergoes gradual decondensation, whereas the granular component appears unchanged. This effect does not fit into any of the published variants of nucleolar alterations.

The synthesis and processing of the ribosomes in the nucleolus last 30 to $60 \mathrm{~min}$, whereas the turnover time of ribosomes in the cytoplasm is around $6 \mathrm{~h}$ (Alberts et al. 1989). From this data and the observation that in lytic cells of prawns the rER is still studded with ribosomes, it can be concluded that the time span between the first stage of pathology and cell lysis is hours rather than days. Surprisingly, the pre-ribosomes of the granular component are not processed after the removal of the fibrillar component. This may be due to inhibition of the respective enzymes, to regulatory disturbances or to inhibition of transport mechanisms.

The decondensation of the fibrillar component is accompanied by decondensation of nuclear hetero- chromatin. The structure and function of both kinds of heterochromatin, constitutive and facultative, is not yet understood (John 1988). Constitutive heterochromatin is composed predominantly of noncoding, largely repetitive DNA and, therefore, appears to represent a kind of structural rather than physiological state of chromatin (John 1988). According to Nicolini (1988), it has an important function in creating fixed sites for the attachment of nucleofilaments which can yield DNA locally for transcription. Facultative heterochromatin in contrast, contains coding genes which are turned off it is only condensed during distinct periods. The pattern of heterachromatin can be influenced by a variety of experimental means (Ghadially 1988). Stimulants of transcription, for instance, reduce the amount of heterochromatin. Under these conditions heterochromatin reduction is accompanied by the enlargement of the nucleolus. In our Leucaena-fed prawns, however, heterochromatin is decondensed without nucleolar hypertrophy.

Leucaena-induced decondensation of the fibrillar component of the nucleolus and of heterochromatin may be caused by one and the same mechanism. The toxic agent may interfere with structural elements of both cytological components. The DNA-to-cytoskeleton binding in heterochromatin and nucleolar fibrillar component is possibly disturbed by mimosine or its metabolites. If this hypothesis is true, then euchromatin should also be affected resulting in nucleoplasm fading as observed in this study.

Early injuries to the cytoplasm and organelles. Cells most often respond to toxicants with adaptive structural alterations of the cytoplasmic compartment which are considered non-pathological. These include proliferation of sER (reflecting enhanced detoxification, Klaunig et al. 1979), proliferation of lysosomes (as often occurs after exposure to heavy metal burdening, Segner 1987), and depletion of reserves such as glycogen and lipid (interpreted as energy mobilization for the detoxification processes).

In the Leucaena-fed prawns of this study, the enhancement of the number of lysosomal autophagosomes in unfaded R-cells (Vogt et al. 1986) may be interpreted as first adaptive process to Leucaena intoxication. Autophagosome proliferation is accompanied by alterations of the Golgi vesicles, the content of which is most probably released into the autophagosomes. As fading cells lack these autophagosomes, their role as first detoxification mechanism seems all the more plausible. Mimosine may be stored in this compartment, in a chemically bound form, and thus be detoxified. Neither ER proliferation nor signs of membrane damage - such as enlargement of the cell by water influx, mitochondrial swelling and dilatation of the Golgi cisternae (Moore \& Lowe 1985) - 
were observed in the early stages of pathology. Therefore, it can be concluded that the toxic Leucaena ingredient apparently does not induce ER-related detoxification pathways and does not injure the membranes. Mitochondrial swelling without cell hypertrophy occurred in midgut gland-cells of Penaeus monodon after intoxication with acute toxic concentrations of the insecticide dimethoate (Vogt 1987) and after prolonged starvation (Vogt et al. 1985). Golgi hypertrophy was observed after virus infection (Lightner et al. 1983).

The most obvious early alterations of the cytoplasm and its organelles in pathological cells were fading of the cytoplasm, darkening of the mitochondrial matrix, and vacuolization of the dictyosomes in F-cells. The dark-light problem of the cytoplasm in pathology is still unsolved (Ghadially 1988). Dark and light cells can be observed in both normal and pathologically altered tissues. Fading is often combined with cell enlargement and is explained as a result of membrane damage. In contrast, darkening is interpreted as water efflux followed by cell shrinkage and subsequent cell death (Ghadially 1988). In this study, however, fading and darkening was not combined with alterations in cell size. The often claimed correlation between cytoplasm darkening and metabolical inactivity is with high probability true for mature B-cells of the decapod midgut gland under non-pathological conditions. In the case of R-cells after Leucaena feeding, however, this hypothesis fails, since it is the light cells that undergo death, whereas those with darker cytoplasm do not display any further cytological alteration. Gradual fading of the cytoplasm in midgut gland-cells without parallel nuclear effects has previously been reported during starvation (Vogt et al. 1985). This kind of fading, however, is due to degradation of cytoplasmic constituents and is accompanied by a dramatic reduction of all cell organelles. It is thus not comparable to the Leucaena-induced cytoplasm fading. Cytoplasm fading after Leucaena feeding may reflect a complex result of inhibition of pyridoxal phosphate or metaldependent enzymes by mimosine, thus leading to a general shortage of cytoplasmic constituents.

Mitochondria with condensed matrices are often interpreted as 'low energy state' organelles with reduced oxidative phosphorylation (Ghadially 1988). This would sooner or later result in an ATP-shortage in cells. Since the electron transport chain contains metalloenzymes, the enzyme inhibition hypothesis for mimosine toxicity may also be brought into play as the explanation of mitochondria darkening

Vacuolization of dictyosomes in F-cells at a very early pathological stage may be caused by the influence of mimosine on the microtubular system which is believed to maintain the Golgi architecture (Pavelka 1987). Pavelka \& Ellinger (1983) observed vesiculation of the Golgi cisternae in rat pancreatic acinar cells after the application of colchicine, a classical agent for the prevention of tubulin polymerization. The dictyosomes were only vesiculated in pancreas but not in small intestine cells (Ellinger \& Pavelka 1984). Surprisingly, this observation resembles our findings, since the dictyosomes of R-cells (which integrate 'intestinal' and 'hepatic' functions) did not vacuolize, whereas the dictyosomes of F-cells ('pancreatic', synthesis of digestive enzymes) did. In B-cells of Penaeus monodon, the dictyosomes were also vacuolated, but later than in F-cells and to a lesser degree. The various reactions of the dictyosomes in the midgut gland-cells seem to indicate not only functional but structural differences of the respective organelles.

Until now, cytoskeleton disturbances by Leucaena or mimosine application were only reported in mitosis. In our experiment, mitosis of E-cells at the blind-end of tubules was apparently not affected. The slight alterations of the tubular organization in Leucaena-fed prawns (which was observable earlier than the first cytopathological signs) may be related to disturbances of the cytoskeleton.

Most of the less frequent signs detected in the early stages of cell injury can be considered as Leucaenadependent effects, since they were not observed in the soybean control. Some alterations may be interpreted as pathological: flocculent precipitates in the mitochondrial matrix, for instance, are believed to consist of denaturated proteins and are interpreted as irreversible damage of the respective organelle (Trump et al. 1981).

Pathological alterations during cell lysis. The final stage of pathology in all midgut gland-cells, i.e. cell lysis, largely follows the scheme given by Trump et al. (1981) for this stage of necrosis: the mitochondrial matrix becomes electron light, the dictyosomes of R-cells undergo atrophy and the other cell organelles subsequently disrupt. Finally, the plasma membrane ruptures and the cell content is released.

According to Trump et al. (1981), in dying cells the nucleus undergoes mostly karyolysis. In contrast, Moore \& Lowe (1985) argue for pyknosis as the most common final nuclear stage. Trump et al. (1981) reported on marginal condensation of the chromatin prior to karyolysis. In Leucaena-fed postlarvae, however, heterochromatin was removed step-by-step. Contrary reactions of the midgut gland-cell nuclei in Penaeus monodon were observed after starvation and insecticide intoxication. In long-term starved prawns, chromatin completely condensed along the nuclear envelope. No nuclear changes were observed in dying prawns after dimethoate application, although the cytoplasm and its contents were completely lysed (Vogt 1987). 


\section{CONCLUSIONS}

The alterations in the nucleolus and heterochromatin of Penaeus monodon postlarvae after Leucaena feeding obviously represent primary injuries, which are most likely responsible for eventual cell lysis. Some alterations of cytoplasmic compartments, such as cytoplasm fading, mitochondria darkening and vacuolization of F-cell dictyosomes occur almost as early as the first nuclear damages. They, therefore, seem to arise independently from nuclear disorders.

Acknowledgements. Thanks to F. P. Pascual, Ph.D. and E.T Quinitio, M.Sc. (SEAFDEC, Philippines) for excellent cooperation, M. Suhm for skillful technical assistance, G. Adam for careful reproduction of the micrographs. and Dr T. Braunbeck for critical comments.

\section{LITERATURE CITED}

Alberts, B., Bray, D., Lewis, J., Raff, M., Roberts, K., Watson, J. D. (1989). Molecular biology of the cell, 2nd ed. Garland Publishing Inc., New York

Al-Mohanna, S. Y., Nott, J. A. (1986). B-cells and digestion in the hepatopancreas of Penaeus semisulcatus (Crustacea: Decapoda). J. mar biol. Ass. U.K. 66: 403-414

Caceci, T., Neck, K. F., Lewis, D. H., Sis, R. F. (1988). Ultrastructure of the hepatopancreas of the pacific white shrimp. Penaeus vannamei (Crustacea, Decapoda). J. mar biol. Ass. U.K. 68: 323-337

Chang, L. $-T$ (1960). The effect of mimosine on alkaline phosphatase of mouse kidney. J. Formosan Med. Ass. 59: $882-888$

Daskal, Y (1979). Drug effects on nucleolar and extranucleolar chromatin. In: Busch, H., Crooke, S. T., Daskal, Y (eds.) Effects of drugs on the cell nucleus. Academic Press, New York, p. 107-124

Dewreede, S., Wayman, O. (1970). Effect of mimosine on the rat fetus. Teratology 3: 21-27

DeWys, W. D., Hall, T C. (1973). Studies on the effect of tumor type and route of administration on the antitumor activity of the amino acid mimosine (NSC-69188). Cancer Chemother. Rep. 57: 41-49

Ellinger, A., Pavelka, M. (1984). Colchicine-induced tubular, vesicular and cisternal organelle aggregates in absorptive cells of the small intestine of the rat. I. Morphology and phosphatase cytochemistry. Biol. Cell 52; 43-52

Ghadially, F. N. (1988). Ultrastructural pathology of the cell and matrix, vol I and II, 3rd edn. Butterworth, London

Hegarty, M. P., Lee, C. P., Christie, G. S., Court, R. D., Haydock, K. P. (1979). The goitrogen 3-hydroxy-4(1H)pyridone, a ruminal metabolite from Leucaena leucocephala: effects in mice and rats. Aust. J. Biol. Sci. 32: $27-40$

Hegarty, M. P., Lee, C. P., Christie, G. S, De Munk, F. G., Court, R. D. (1978). Comparative toxicities of mimosine and some chemically related compounds to mouse bone marrow cells in liquid culture. Aust. J. Biol. Sci. 31: $115-121$

Hegarty, M. P., Schinckel, P. G., Court, R. D. (1964). Reaction of sheep to the consumption of Leucaena glauca Benth. and to its toxic principle mimosine. Aust. J. agric. Res. 15: 153-167

Holmes, J. H. G., Humphrey, J. D., Walton, E. A., O'Shea, J. D. (1981). Cataracts, goitre and infertility in cattle grazed on an exclusive diet of Leucaena leucocephala. Aust. vet. J. 57: $257-261$

John, B. (1.988). The biology of heterochromatin. In: Verma, R. S. (ed.). Heterochromatin: molecular and structural aspects. Cambridge University Press, Cambridge, p. 1-147

Jonos, R. J. (1979). The value of Leucaena leucocephala as a feed for ruminants in the tropics. Wld anim. Rev. 31: 13-23

Jones, R. J., Hegarty, M. P. (1984). The effect of different proportions of Leucaena leucocephala in the diet of cattle on growth, feed intake, thyroid function and urinary excretion of 3-hydroxy-4(1 H)-pyridone. Aust. J. agric. Res. 35: $317-325$

Jones, R. J., Megarrity, R. G. (1986). Successful transfer of DHP-degrading bacteria from Hawaiian goats to Australian ruminanis to overcune the toxicity of Leucaena. Aust. Vet. J. 63: 259-262

Klaunig, J. E., Lipsky, M. M., Trump, B. F., Hinton, D. E. (1979). Biochemical and ultrastructural changes in teleost liver following subacute exposure to PCB. J. Environm. Path. Toxicol. 2: 953-963

Lightner, D. V., Redman, R. M., Bell, T A. (1983). Observations on the geographic distribution, pathogenesis and morphology of the baculovirus from penaeus monodon Fabricius. Aquaculture 32: 209-233

Lin, J.-Y., Shih, Y.-M., Ling, K.-H. (1962). Studies on the mechanism of toxicity of mimosine ( $\beta$ - $(\mathrm{N}-\{3-\mathrm{hydroxy}$ pyridone])- $\alpha$-aminopropionic acid). (1) Studies on the reactions of mimosine and pyridoxal 5-phosphate using the spectrophotometric method. J. Formosan Med. Ass. 61: 997-1003

Loizzi, R. F. (1971). Interpretation of crayfish hepatopancreatic function based on fine structural analysis of epithelial cell lines and muscle network. Z. Zellforsch. 113: 420-440

Megarrity, R. G., Jones, R. J. (1983). Toxicity of Leuczena leucocephala in ruminants: the effect of supplemental thyroxine on goats fed on a sole diet of Leucaena. Aust. J. agric. Res. 34: 791-798

Montagna, W., Yun, J. S. (1963). The effects of the seeds of Leucaena glauca on the hair follicles of the mouse. J Invest. Dermatol. 40: 325-332

Moore, M. N., Lowe, D. M. (1985). Cytological and cytochemical measurements. In: Bayne, B. L., Brown, D. A., Burns K., Dixon, D. R., Ivanovici, A., Livingstone, D. R., Lowe, D M. Moore, M. N., Stebbing, A. R. D., Widdows, J. (eds.) The effects of stress and pollution on marine animals Praeger, New York, p. 46-74

NAS (1977). Leucaena, promising forage and tree crop for the tropics. National Academy of Sciences, Washington, DC

Nicolini, C. (1988). Nuclear architecture and three-dimensional organization of chromatin: their role in the control of cell function. In: Verma, R. S. (ed.) Heterochromatin molecular and structural aspects. Cambridge University Press, Cambridge, p. 228-249

Pascual, F. P., Tabbu, N. S. (1980). Ipil-ipil (Leucaena leucocephala) leaves as plant protein source in prawn diets. Aquaculture Department, SEA.FDEC, Quarterly Research Report 4: 1-4

Pavelka, M. (1987). Functional morphology of the Golgi apparatus. Adv. Anat. Embryol. Cell. Biol. 106: 1-94

Pavelka, M. Ellinger, A. (1983). Effect of colchicine on the Golgi complex of rat pancreatic acinar cells. J. Cell Biol 97: $737-748$

Prabhakaran, K., Harris, E. B., Kirchheimer, W. F. (1973). A 
specific effect of mimosine on melanoma cells. Cytobios 7 : 245-252

Pritchard, A. J., Court, R. D. (1968). The cytological effects of mimosine. Cytologia 33: 73-77

Reis, P. J., Tunks, D. A., Chapman, R. E. (1975). Effects of mimosine, a potential chemical defleecing agent, on wool growth and the skin of sheep. Aust. J. Biol. Sci. 28: 69-84

Roldan, B. M., Shivers, R. R. (1987). The uptake and storage of iron and lead in cells of the crayfish (Orconectes propinquus) hepatopancreas and antennal gland. Comp. Biochem. Physiol. 86C: 201-214

Segner, H. (1987). Response of fed and starved roach, Rutilus rutilus, to sublethal copper contamination. J. Fish Biol. 30: $423-437$

Serrano, E. P., Ilag, L. L., Mendoza, E. M. T. (1983). Biochemical mechanisms of mimosine toxicity to Sclerotium rolfsii Sac. Aust. J. biol. Sci. 36: 445-454

Stahl, A. (1982). The nucleolus and nucleolar chromosomes. In: Jordan, E. G., Cullis, C. A. (eds.). The nucleolus. Cambridge University Press, Cambridge, p. 1-24

Tangendjaja, B., Lowry, J. B., Wills, R. B. H. (1984) Optimization of conditions for the degradation of mimosine in Leucaena leucocephala leaf. J. Sci. Fd Agric. 35: 613-616

Triebskorn, R. (1989). Ultrastructural changes in the digestive tract of Deroceras reticulatum (Müller) induced by a carbamate molluscicide and by metaldehyde. Malacologia 31: $141-156$

Trump, B. F., Berezesky, I. K., Osornio-Vargas, A. R. (1981). Cell death and the disease process. The role of calcium. In: Bowen, 1. D., Lockshin, R. A. (eds.) Cell death in biology and pathology. Chapman and Hall, London, New York, p. $209-242$

Responsible Subject Editor: Dr J. E. Stewart, Dartmouth, N.S., Canada
Tsai, W.-C., Ling, K.-H. (1971). Toxic action of mimosine. I. Inhibition of mitosis and DNA synthesis of H.Ep-2 cell by mimosine and 3,4-dihydroxypyridine. Toxicon 9 ; $241-247$

Tsai, W.-C., Ling, K.-H. (1973). Study on the stability constant of some metal ion chelates of mimosine and 3,4-dihydroxypyridine. J. Chin. Biochem. Soc. 2: 70-86

Vogt, G. (1985). Histologie and Cytologie der Mitteldarmdrüse von Penaeus monodon (Decapoda). Zool. Anz. 215: $61-80$

Vogt, G. (1987). Monitoring of environmental pollutants such as pesticides in prawn aquaculture by histological diagnosis. Aquaculture 67: 157-164

Vogt, G, Quinitio, E. T., Pascual, F. P. (1986). Leucaena leucocephala leaves in formulated feed for Penaeus monodon: a concrete example of the application of histology in nutrition research. Aquaculture 59: 209-234

Vogt, G., Stöcker, W., Storch, V., Zwilling, R. (1989). Biosynthesis of Astacus protease, a digestive enzyme from crayfish. Histochemistry $91: 373-381$

Vogt, G., Storch, V., Quinitio, E. T., Pascual, F. P. (1985). Midgut gland as monitor organ for the nutritional value of diets in Penaeus monodon (Decapoda). Aquaculture 48: $1-12$

von Sallmann, L., Grimes, P., Collins, E. (1959). Mimosine cataract. Am. J. Ophthalmol. 47: 107-117

Ward, K. A., Harris, R. L. N. (1976). Inhibition of wool follicle DNA synthesis by mimosine and related $4(1 \mathrm{H})$-pyridones. Aust. J. Biol. Sci. 29: 189-196

Wee, K. L., Wang, S.-S. (1987). Nutritive value of Leucaena leaf meal in pelleted feed for nile tilapia. Aquaculture 62: $97-108$

Manuscript first received: November 28, 1989

Revised version accepted: May 15, 1990 